\title{
DRAFT
}

\section{ISSUE PAPER}

POTENTIAL WATER AVAILABILITY PROBLEMS ASSOCIATED WITH GEOTHERMAL ENERGY OPERATIONS

FEBRUARY 19, 1982

\author{
Prepared for: \\ Geothermal and Hydropower Technologies Division \\ U.S. Department of Energy \\ Project officers: \\ A. David Allen \\ Prepared by: \\ Engineering and Economics Research Inc. \\ 1951 Kidwell Drive, Suite 201 \\ Vienna, Virginia 22180 \\ Contract No.: DE-AC-07-80-ID 12183 \\ EER Project No.: ET15E
}




\section{DISCLAIMER}

This report was prepared as an account of work sponsored by an agency of the United States Government. Neither the United States Government nor any agency Thereof, nor any of their employees, makes any warranty, express or implied, or assumes any legal liability or responsibility for the accuracy, completeness, or usefulness of any information, apparatus, product, or process disclosed, or represents that its use would not infringe privately owned rights. Reference herein to any specific commercial product, process, or service by trade name, trademark, manufacturer, or otherwise does not necessarily constitute or imply its endorsement, recommendation, or favoring by the United States Government or any agency thereof. The views and opinions of authors expressed herein do not necessarily state or reflect those of the United States Government or any agency thereof. 


\section{DISCLAIMER}

Portions of this document may be illegible in electronic image products. Images are produced from the best available original document. 
List of Exhibits

1.0 INTRODUCTION 1

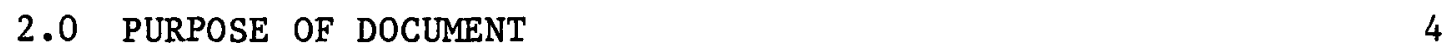

3.0 SCOPE OF DOCUMENT

$\begin{array}{lll}4.0 & \text { CONCLUSIONS } & 8\end{array}$

$\begin{array}{lll}5.0 & \text { DISCUSSION } & 12\end{array}$

5.1 What are the water requirements associated 12 with geothermal energy development?

5.2 What water availability problems are associated with geothermal energy development and what are the underlying causes of these problems?

$\begin{array}{lll}5.3 & \text { How severe are the water availability problems? }\end{array}$

5.4 Why are water availability problems important to 26 geothermal energy development?

5.5 What are the typical procedures for the acquisition 28 of water for geothermal energy development?

5.6 What are the possible technical alternatives to reducing water requirements for geothermal power plants?

5.7 What are the unconventional solutions?

5.8 What are the legal/institutional constraints of the water avallability problems?

5.9 What are the federal regulations affecting water resource and use allocation?

5.10 What are the state and local regulations affectting water resource use and allocation?

5.11 What are the roles of the various levels of government and their efforts in addressing the various problems associated with water availability?

5.12 What types of $R \& D$; and planning and management efforts are required to resolve the water availability problem? 
TABLE OF CONTENTS (Concluded)

\section{Page}

5.13 How is the Division of Geothermal and Hydropower Technology's Environmental Control Technology Program addressing the water availability problems?

REFERENCES 
Page

1.1 Comparison of Critical Water Supply Areas and Known 3 Geothermal Resource Areas

3.1 Flow Diagram of Water Availability Problems Associa- 7 ted with Geothermal Energy Operation

4.1 Water-related Problems and Recommended Activities to Alleviate Such Problems

5.1 Simplified Flow Diagrams of Fossil-Fuel Power Plant and Geothermal Power Plant

5.2 Comparison of the Water Consumption of Fossil-Fuel

Power Plant and Geothermal Power Plant

5.3 Make-up Water Requirements as a Function of Thermal

Efficiency and Concentration Factor

5.4 Cooling Tower Make-up Water Requirement as a Function of Resource Temperature and Climatologica1 Conditions

5.5 Water Supply Related Problems 20

5.6 Comparison of Consumptive Water Usage of Electric 22 Power Generation Facilities

5.7 Summary Highlights of Water Availability Problems in 34 Known Geothermal Resource Areas

5.8 Typical Procedure for the Acquisition of Water

5.9 Comparison of Different Cooling Systems that

Have Potential Application to Geothermal Power Plants

5.10 Interface Between the Natural System and Legal System

5.11 Comparison of the Major Characteristics of the Surface Water Legal Systems

5.12 Surface Water Legal Systems in the U.S.

5.13 Some Common Legal/Institutional Constraints Asso- 43 ciated with Geothermal Development

5.14 Major Federal Legislations Affecting Water Resources 46 for Geothermal Development 
5.15 State Laws and Regulations Pertaining to Geothermal 50 Energy Development

5.16 Comparison of Water Use Allocation System with Known 52 Geothermal Resource Areas

5.17 Major Legislative Elements and Their Constraints on 53 Geothermal Energy Development in the Western States

5.18 Major Federal Agencies and Their Responsibilities 60 in Water Resources

5.19 Major R\&D and Planning and Mangement Activities Required to Address Water Availability Problems 


\subsection{INTRODUCTION}

Geothermal energy resources have the potential of making a significant contribution to the U.S. energy supply situation, especially at the regional and local levels where the resources are located. At present over 920 megawatts (MWe) of geothermally-produced electric power are currently on-line in this country and there are over 200 operational direct-heat projects using geothermal energy. Among the various environmental problems associated with geothermal production, concern has recently been focussed on waterrelated issues. Hydrological effects relative to geothermal fluid withdrawal and subsurface disposal are important water-related issues that have been addressed previously.1 Another issue of concern is the availability of water for use in a geothermal power operation.

The U.S. Department of Energy (DOE) through its Geothermal and Hydropower Technology Division (GHTD), is addressing a full range of environmental problems associated with geothermal. However, no studies have been specifically performed to identify the water requirements of geothermal power plants, the underlying causes of water availability problems, and available techniques to alleviate some of these problems.

The availability of water for geothermal power plant uses is an important concern in geothermal development primarily because geothermal power plants required large quantities of water for cooling, sludge handling and the operation of environmental control systems. On a per unit power output basis, geothermal power plants, because of their inherent high heat rejection rates, have cooling requirements several times greater than the conventional fossil fuel 
plants. Thus the assured availability of water is an important factor in the planning, designing, and siting of geothermal power plants.

The water availability problem is further exacerbated by the fact that expanded development of geothermal energy particularly hydrothermal energy for power generation, is expected to occur in the southwest, where the water supply situation is already critical.2 Exhibit 1.1 compares the critical water supply areas in the U.S. with the hydrothermal resources. As evident in this exhibit, a majority of the high temperature geothermal resources is located in critical water shortage areas.

Water availability problems can be classified into "real" or "perceived". The former relates to limited physical availability with complications caused by annual and seasonal variations. The latter refers to the various legal/institutional and sometimes emotional constraints imposed upon the re-allocation or re-appropriation of water. Water supply problems and their effects on geothermal development will be discussed in this document. 

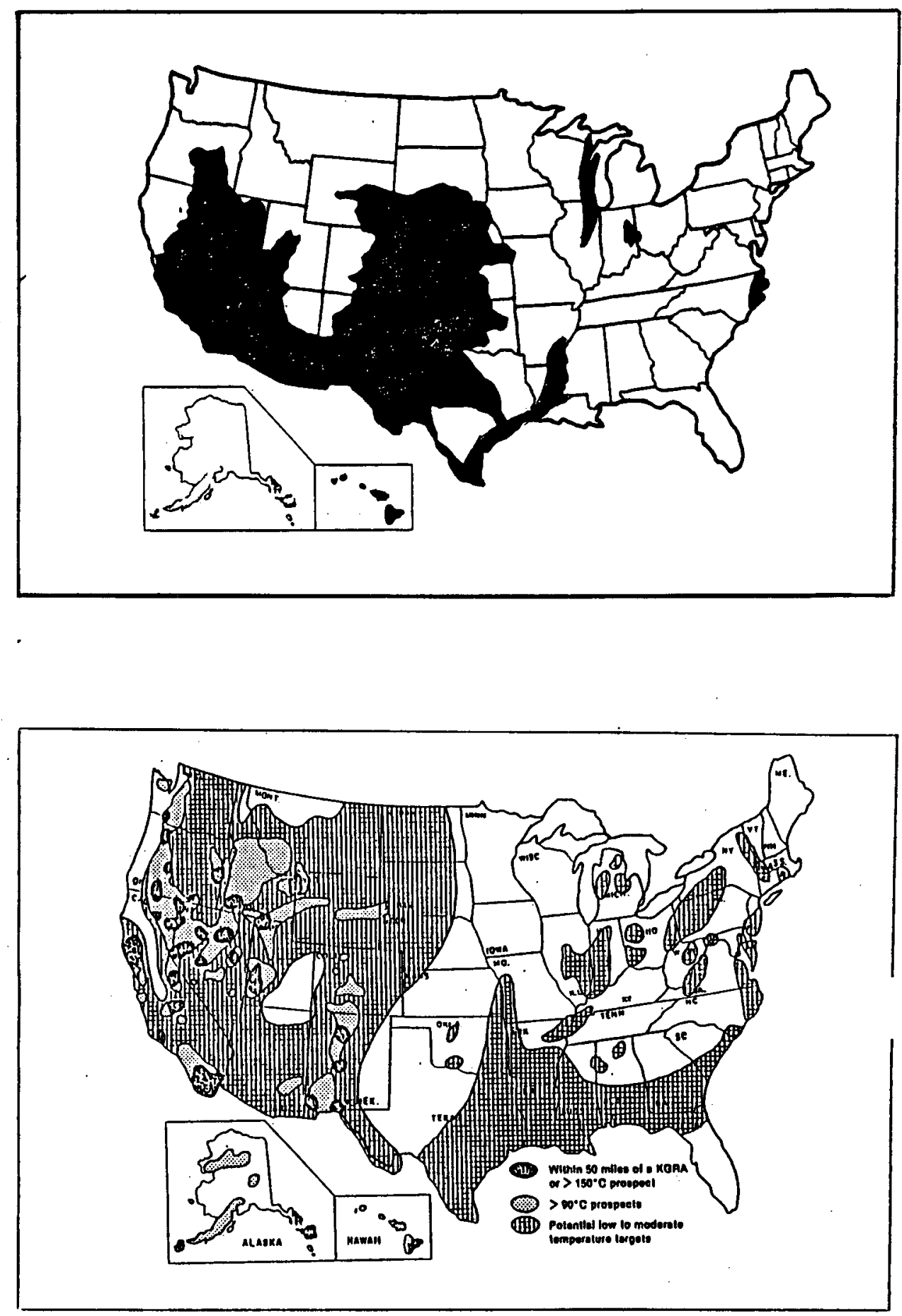

EXHIBIT 1.1

COMPARISON OF CRITICAL WATER SUPPLY

AREAS AND KNOWN GEOTHERMAL RESOURCE AREAS 


\subsection{PURPOSE}

The lack of steady reliable sources of water supply is being recognized as one of the major barriers to the large-scale expansion of geothermal energy. Since many hydrothermal reservoirs are located in regions of limited water availability, this lack of water resources could result in unwanted delays, plant shutdowns, or operation at below design capacity. In addition, because water use conflicts tend to be very site specific, detailed engineering analysis will also be needed to identify potential and available water resources within a site. Therefore, the main purpose of this document is to:

- identify generic water availability problems associated with geothermal development.

- document, to the extent possible, site specific water availability problems.

- explore the alternative solutions to water availability problems,

- identify further research and development, and planning and coordination needs to address water related problems.

Since this document is intended to be used as an internal DOE management tool for geothermal energy planning and decision making, it is organized in a "question-and-answer" format for easy readings. The questions relate to major issues and concerns, while the answers represent the understanding of such issues. Sometimes the lack of a definitive answer to a question may imply more R\&D would be needed in that area. 
3.0 SCOPE

In addressing the water availability problem, we have presented our discussion according to thirteen (13) discrete issues and/or concerns as identified below:

1. What are the water requirements associated with geothermal energy development?

2. What water availability problems are associated with geothermal energy development and what are the underlying causes of these problems?

3. How severe are the water avallability problems?

4. Why are water availability problems important to geothermal energy development?

5. What are the typical procedures for the acquisition of water for geothermal energy development?

6. What are the possible technical alternatives to reducing water requirements for geothermal power plants?

7. What are the unconventional solutions?

8. What are the legal/institutional constraints of the water availability problems?

9. What are the federal regulations affecting water resource and use allocation?

10. What are the state and local regulations affecting water resource use and allocation?

11. What are the roles of the various levels of government and their efforts in addressing the various problems associated with water availability?

12. What types of R\&D; and planning and management efforts are required to resolve the water availability problem?

13. How is the Division of Geothermal and Hydropower Techno1ogy's Environmental Control'Technology Program addressing the water availability problems?

These issues are in many ways interrelated. The first five questions relate to problem identification. By comparing the geothermal water-related problems with other energy options, these 
problems can be put in perspective. The next six questions delineate obstacles related to water availability issues and possible solutions to such issues. Finally, the last two questions detail efforts needed to help mitigate such water availability problems. Exhibit 3.1 shows in a flowchart format the inter-relationship of the waterrelated issues to be discussed in this paper. 
EXHIBIT 3.1

FLOW DIAGRAM OF WATER AVAILABILITY

PROBLEMS ASSOCIATED WITH GEOTHERMAL

ENERGY OPERATION

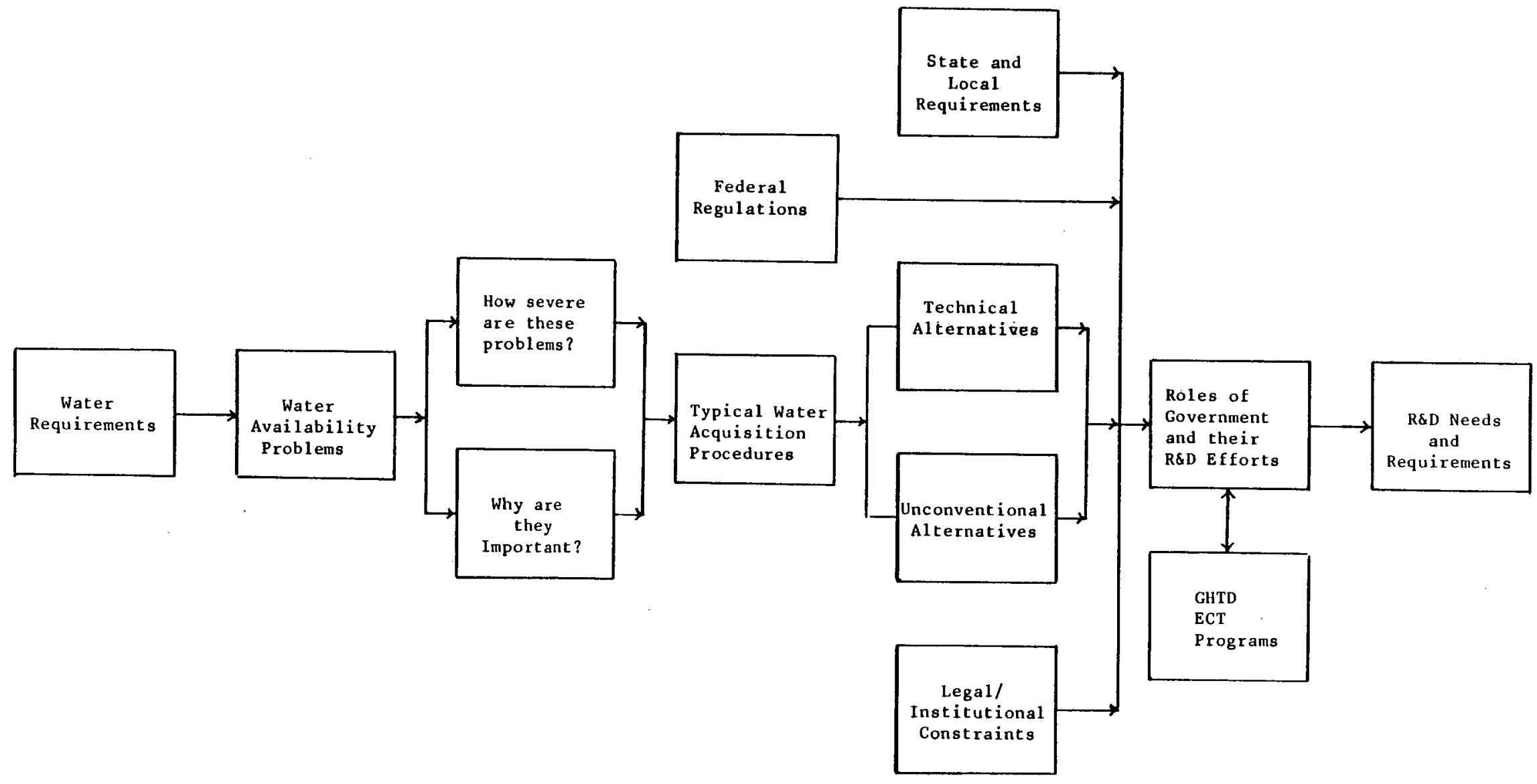




\subsection{CONCLUSION AND RECOMMENDATION}

The operation of geothermal power plants requires a significant amount of water for cooling. Although the nation as a whole does not have any forseeable water supply problems, regional shortages exist particularly in the arid southwest where hydrothermal developments are expected to occur. This document identifies the water problems related to geothermal development. Specific findings of this report are:

- The amount of water consumed for energy processes is relatively small compared to agricultural uses. Despite this, water availability is going to be a severe constraint to hydrothermal development due to unbalance distribution of water and the legal/institutional systems affecting its appropriation.

- Water availability problems can be classified as "real" or "perceived". The former refers to physical availability, coupled with annual and seasonal shortages. The latter occurs when the limited available water resources are totally allocated, making it difficult for any new users to acquire water rights.

- Water requirements for geothermal power plants are several times higher than a conventional fuel power plant on a unit power output basis. However, because the typical installed capacity of fossil fuel plants are 10 to 20 times higher than that of a geothermal plant, water requirements for a fossil fuel plant would be higher than that of a geothermal plant.

- Use of dry cooling towers, or wet/dry cooling towers are the most direct methods for reducing water consumption. However, because of the low efficlency of these cooling systems, bigger structures are required, adding to a substantial increase in capital cost.

- Alternate sources of water are available for geothermal power plant uses. Desalination and the use of brackish water appear to be promising alternatives. Cost is a major factor deterring the widespread use of such systems.

- The most prevalent legal/institutional constraint to the obtaining of water for geothermal power plant use is the manner in which the water is appropriated. Most western states place extremely high priority for agricultural use of water, making it difficult to obtain water rights for geothermal uses. 
- Of the 34 KGRA's surveyed in this report, only five of them appear to have water readily available for geothermal uses. For most other sites, the water is totally allocated. Water rights have to be transferred in these KGRA's.

- There are many federal agencies involved in water resources and water quality monitoring and evaluations. State agencies mainly have enforcement and regulatory functions. Local and county government have significant influence on geothermal development through land use planning and zoning ordnances.

Water availability problems related to geothermal development are very site specific. A nationwide abundance of water does not lessen the problem of locallzed shortages and localized shortages of surface water does not necessarily indicate a shortage of groundwater. It is beyond the scope of DOE/GHTD to perform site specific studies. However, the following type of activities are appropriate DOE/GHTD functions; and its implementation may help to alleviate some of the major water availability problems.

- Perform state-of-the-art review and evaluation of cooling tower technologies, identifying to what extent cool tower designs for fossil fuel plants can be scaled down and used in geothermal power plant operations. The design and operation parameters for water conservation cooling towers are important factors to be ocnsidered.

- Study the technical feasibility and potential economic advantages of using saline or brackish water in all aspects of geothermal power plant operations. The environmental implications of such systems should also be investigated.

- Perform feasibility studies of using deep aquifer as water supply sources, considering potential economic benefits and environmental consequences.

- Coordinate with other federal agencies to strengthen databases on water resources, particularly groundwater sources. Develop mechanisms to increase the accessibility of these databases and derive better methods for integrating sharing, analyzing and displaying water resources information.

- Accelerate the existing programs on injection monitoring. Information obtained in injection monitoring can be used to augment existing groundwater databases. 
- Coordinate with state agenccies to streamline the water rights application process, to develop consistant surface and subsurface water laws.

The recommended activities and the problems they designed to address are illustrated in Exhibit 4.1. Many of the DGHT program activities are addressing some aspects of water related issues. There may be a need to integrate all these activities into one program. The Interagency Geothermal Coordinating Council (IGCC) can be used as a mechanism to coordinate water research and water related activities. 
EXHIBIT 4.1

WATER-RELATED PROBLEMS AND

RECOMMENDED ACTIVITIES TO ALLEVIATE

SUCH PROBLEMS

\begin{tabular}{|c|c|}
\hline WATER RELATED PROBLEMS & RECOMMENDED ACTIVITIES \\
\hline - High Water Demand & $\begin{array}{l}\text { - Perform state-of-the-art review and } \\
\text { evaluation of cooling tower technologies, } \\
\text { with emphasis on: } \\
\text { - tower design } \\
\text { - operation parameters } \\
\text { - technology transfer }\end{array}$ \\
\hline - Inadequate Water Supply & $\begin{array}{l}\text { - Perform feasibility studies on use of } \\
\text { saline/brackish water in all aspects of } \\
\text { geothermal operation, with emphasis on: } \\
\text { - technical feasibility } \\
\text { - economic acceptability } \\
\text { - environmental duplications } \\
\text { - Perform feasibility studies on use of } \\
\text { deep aquifers }\end{array}$ \\
\hline - Inadequate Data Base & $\begin{array}{l}\text { - Coordinate with other federal agencies to: } \\
\text { - strengthen data bases } \\
\text { - make data bases readily accessible } \\
\text { - develop better modeling } \\
\text { - Accelerate program on injection monitoring }\end{array}$ \\
\hline $\begin{array}{l}\text { - Difficulties in obtaining } \\
\text { water rights }\end{array}$ & $\begin{array}{l}\text { - Coordinate with state agencies to streamline } \\
\text { permit application processes }\end{array}$ \\
\hline
\end{tabular}




\subsection{DISCUSSION}

5.1 What are the water requirements associated with geothermal energy development?

Geothermal power plants, like conventional fossil fuel plants or nuclear power plants, must dissipate the waste heat to the environment. Fossil fuel plants presently waste about $60 \%$ of their heat input, while nuclear-fuel plants rejects about $70 \%$ of the heat input. Geothermal power plants, because of the low thermal efficiency inherent in the relatively low-temperature heat sources, waste $85 \%$ must reject more than $85 \%$ of the input energy as heat ${ }^{3}$. A common method to dissipate waste heat is the use of wet cooling towers. While this method is effective for the waste heat rejection, it also consumes a large amount of water through the evaporation process. Almost all the water consumed in the for operation of a geothermal power plant is used by the cooling towers to replace, or "make-up" the amount of water lost from the tower by evaporation, drift, and blowdown. Water is also required for other aspects of a geothermal power plant operation, particularly for the $\mathrm{H}_{2} \mathrm{~S}$ abatement systems, but these amounts are relatively small compared to the cooling tower make-up requirements.

Exhibit 5.1 shows highly simplified flow diagrams of a conventional coal-fired power plant and a geothermal power plant. Areas in which make-up water are required are highlighted. The amount of water consumed by these power plants is shown in Exhibit 5.2. Because a typical fossil fuel plant has an installed capacity of $500-1000$ MWe, whereas 50 MWe is more typical for a geothermal power plant, a hypothetical plant of 50 MWe has been created to facilitate comparison. As evidenced in the exhibit, both types of power plants consume 


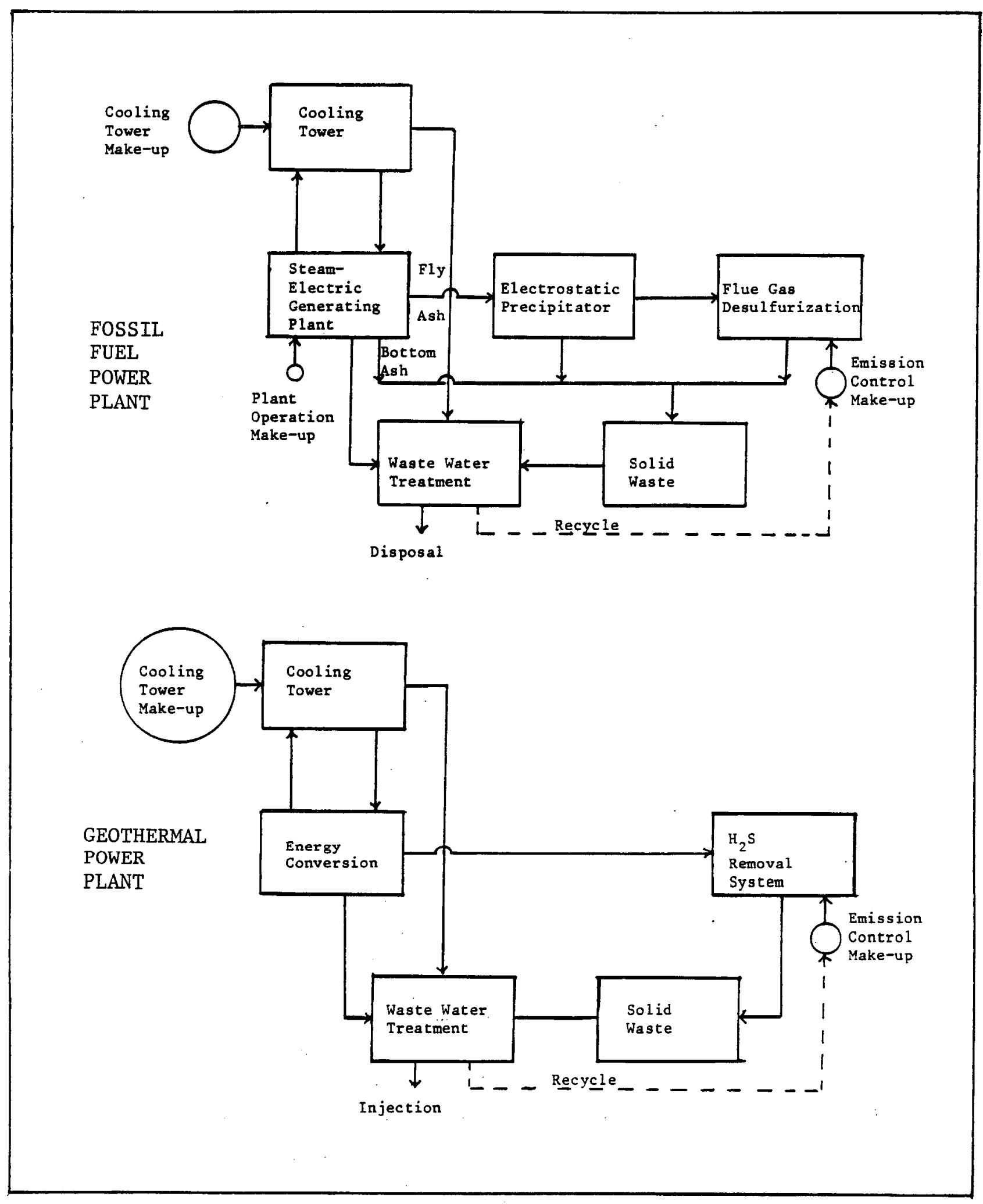

EXHIBIT 5.1

SIMPLIFIED FLOW DIAGRAMS OF FOSSIL-FUEL POWER PLANT AND GEOTHERMAL POWER PLANT

Source: References $3 \& 4$. 


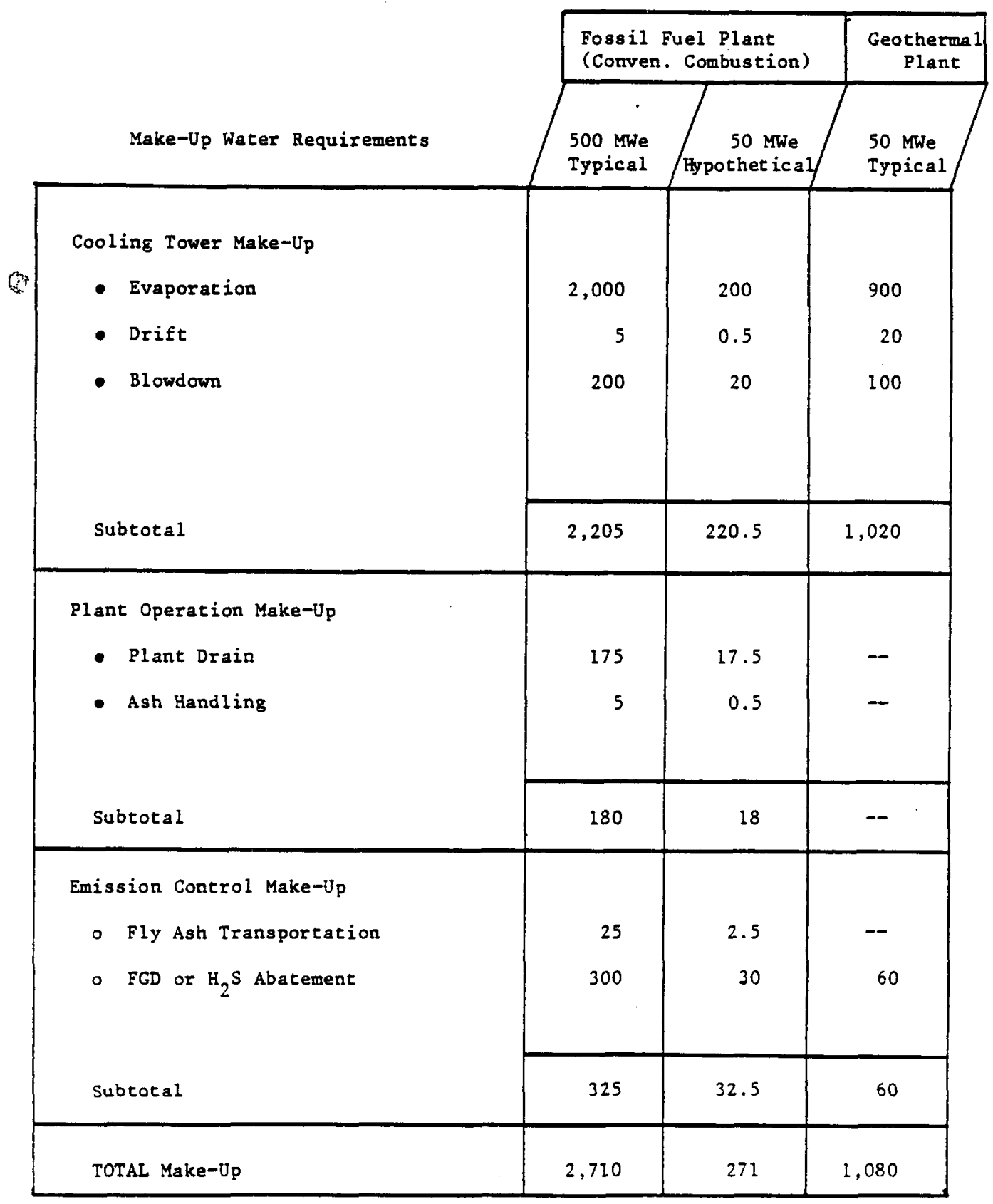

EXHIBIT 5.2

COMPARISON OF THE WATER CONSUMPTION OF FOSSIL-FUEL

POWER PLANT AND GEOTHERMAL POWER PLANT

(MILLIONS OF GALLONS/YEAR)

Source: References $3 \& 4$. 
large quantities of water for cooling, with the geothermal power plant requiring 4 to 5 times as much. On the other hand, because a geothermal power plant has no combustion system, it does not require any water for ash handling and fly ash transportation.

Sometimes, water can be recovered from one process and reused in another. In geothermal power plants, the water from cooling tower blow-down can be used in the $\mathrm{H}_{2} \mathrm{~S}$ abatement system, thereby reducing some of the water consumption. A substantial amount of water can be saved when the condensed steam of a flashed-steam geothermal power plant is used for cooling tower make-up water. SHowever, this is not always possible because many jurisdictions require the injection of spent geothermal fluids to prevent subsidence.

Many factors affect the amount of make-up water required for cooling towers used in geothermal power plants. The thermal efficiency is a major factor as it affects the amount of heat to be dissipated. Other factors include the temperature of geothermal resources, the type of energy conversion units used, the purity of make-up water, the cooling tower design and the meteorological conditions of the sites. Many of these factors are site specific and require detailed analysis to establish water requirements. The following is a brief description of each of these factors:

- Thermal Efficiency. Because the amount of waste heat to be dissipated is proportional to the thermal efficiency of the plant, a small increase in thermal efficiency would increase the power output as well as decrease the cooling water requirement. Exhibit 5.3 shows the amount of water requirements for geothermal power plants as a function of thermal efficiency and concentration factor.

- Concentration Factor. The concentration factor, or cycles of concentration, is defined as the ratio of total dissolved solid (TDS) in the circulating (or blowdown) water to the TDS in the make-up water. Increasing the concentration factor 


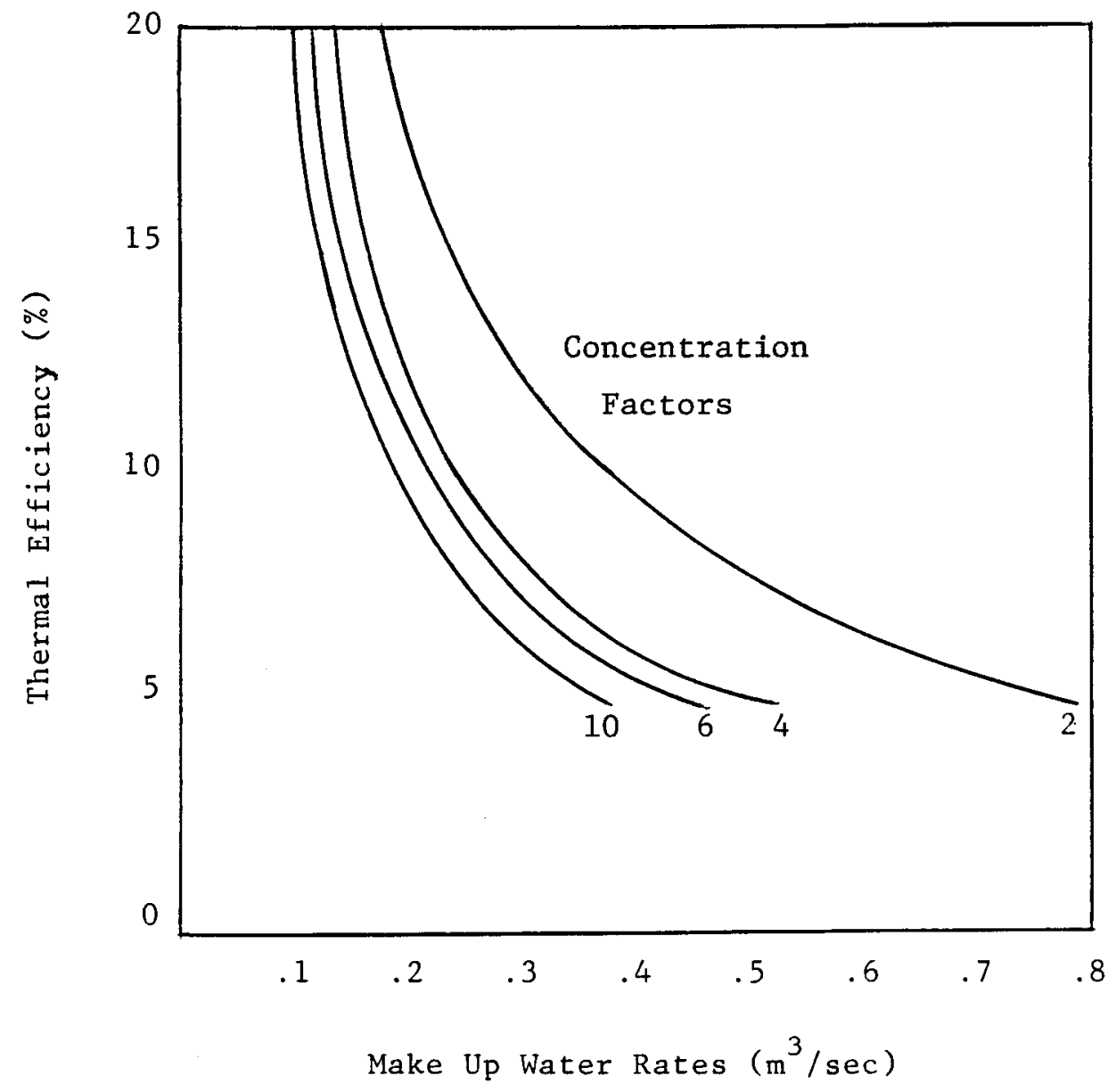

EXHIBIT 5.3

MAKE-UP WATER REQUIREMENTS AS A FUNCTION OF THERMAL EFFICIENCY AND CONCENTRATION FACTOR

Source: Reference 3 
implies decreasing the blowdown rate, thereby decreasing the water consumption requirements.

- Resource Temperature. Other factors being equal, a higher resource temperature would generally imply a higher thermal efficiency, which in turn leads to smaller amounts of make-up water requirement.

- Energy Conversion Systems. Binary cycles, with a resource temperature of $360^{\circ} \mathrm{F}$, use about $17 \%$ more make-up water than flashed-steam systems of the same resource temperature. The working fluids used in binary cycles may also affect the makeup water requirements.

- Quality of Make-up Water. As the water in the cooling tower is being evaporated, the dissolved solid content of the circulating cooling water increases. If the make-up water used has a low dissolved solid content, a higher concentration factor can be used before the dissolved solid content reaches unacceptable level.

- Types of Cooling Towers. Two basic types of cooling towers can be used in geothermal power plants - evaporative (or wet) cooling towers and non-evaporative (or dry) cooling towers. The latter does not require any water for cooling. However, it is a relatively inefficient system, requiring a much larger structure to achieve the same cooling capacity.

- Meteorological Conditions. The temperature to which the circulating water can be cooled in a wet cooling tower is a function of the ambient temperature and relative humidity. These factors affect the rate of evaporation and the amount of makeup water requirements.

Exhibit 5.4 shows the cooling tower make-up water requirement as a function of resource temperature, climatological conditions. For most geothermal power plants, the total make-up water rquirements are estimated to range from 13,000 to 26,000 gallons per year per net kilowatt, assuming a typical energy conversion efficiency of $10 \%$ to $15 \%$ and a plant capacity factor of 0.8 . 


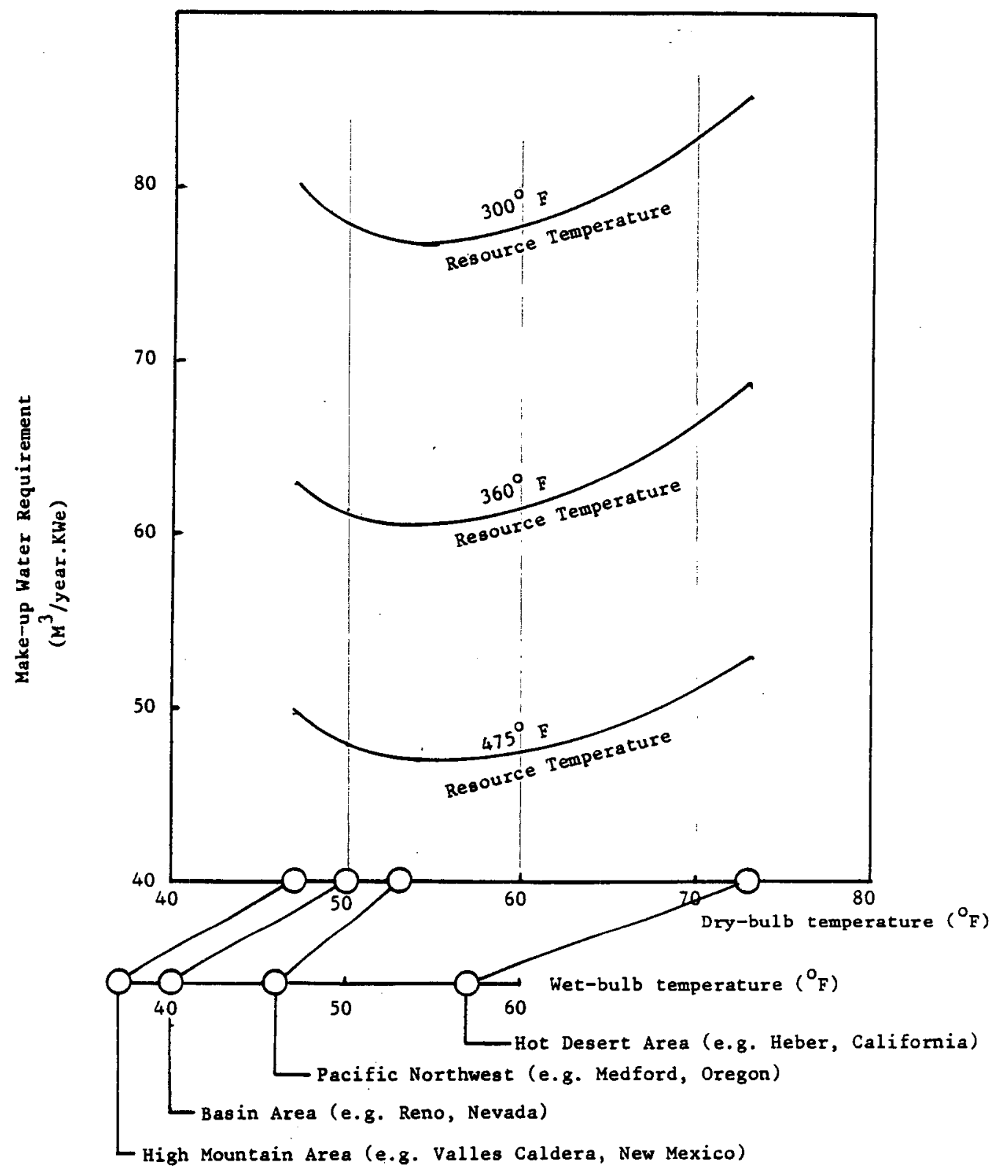

EXHIBIT 5.4

COOLING TOWER MAKE-UP WATER REQUIREMENT AS A FUNCTION OF RESOURCE TEMPERATURE AND CLIMATOLOGICAL CONDITIONS 
5.2 What water availability problems are associated with geothermal energy development and what are the underlying causes of these problems?

Conventional power plants that generate electricity by consuming fuels can be geographically separated from their fuel supply sources, because fuels can be transported, sometimes over long distances, to the point of use. Geothermal power plants, on the other hand, must be located in close proximity to the geothermal resources, because of the impracticality of transporting geothermal fluids over long distances.

According to the U.S. Water Resources Council, water supplies nationwide are generally sufficient to meet current water needs for all beneficlal uses, but local shortages exist. Increasing uses, and competitions among different sectoral uses, create areas of defficiency, particularly in the arid southwest. Unfortunately, most of the high-temperature geothermal resources are located in the arid and semi-arid part of the U.S., where existing water supplies are almost totally allocated. Geothermal energy development will, therefore, have to compete with other water uses, particularly agricultural and industrial uses.

Major water supply problems associated with geothermal energy development are shown in Exhibit 5.5. These problems may be classified as "real" or "perceived". Annual and seasonal shortages are real water supply problems as they limit the physical availability of water for beneficial uses. Water supply problems are exacerbated when two relatively dry years occur bqle-to-back, which is a common phenomenon in the arid southwest. 
EXHIBIT 5.5

WATER SUPPLY RELATED PROBLEMS

- Physical Availability

Annual

Seasonal

- Traditional Uncertainties

Water Rights

Priorities

Restrictions

Increased Competition/Conflicts

- Emerging Concerns

Indian Reserved Rights

Federal Reserved Rights

Instream Values

Quality

Habitat

Endangered Species

Recreation Aesthetics

Wild and Scenic Rivers

Salinity Moratoriums

Court Challenges

- Emotional Issues

Destruction of Lifestyles

Increased Prices for Agriculture 
5.3 How severe are the water availability problems?

The amount of water consumed by a geothermal power plant is generally several times higher than that of a fossil fuel plant on a per unit of power output basis, specifically geothermal power plants using binary energy conversion systems, consume several times more water than other systems. Exhibit 5.6 ranks the consumptive water usages of common electric power generating facilities.

Despite the fact that hydrothermal resources tend to occur in the arid and semi-arid southwest, water availability problems associated with geothermal development are very site specific. Local conditions may vary significantly compared to the water problem on a statewide or water-shed basis. To fully appreciate the water availability problem, it is necessary to analyze the water-related constraints within each known geothermal resource area (KGRA). Site specific information for over 30 KGRAs are summarized in Appendix A. This appendix provides specific information on:

- Potential for geothermal energy development and associated water requirements.

- Availability of surface water and its critical surface supply.

- Availability of groundwater and problems associated with overdraft.

- Major water uses in the area.

- Potential conflict with geothermal use.

Existing supply and commitment to other uses are major factors affecting the potential availability for geothermal uses. Exhibit 5.7 summarizes the site-specific information listed in Appendix A. Only 5 out of the 34 KGRAs appear to have no severe limitations on water supply for geothermal energy development. 


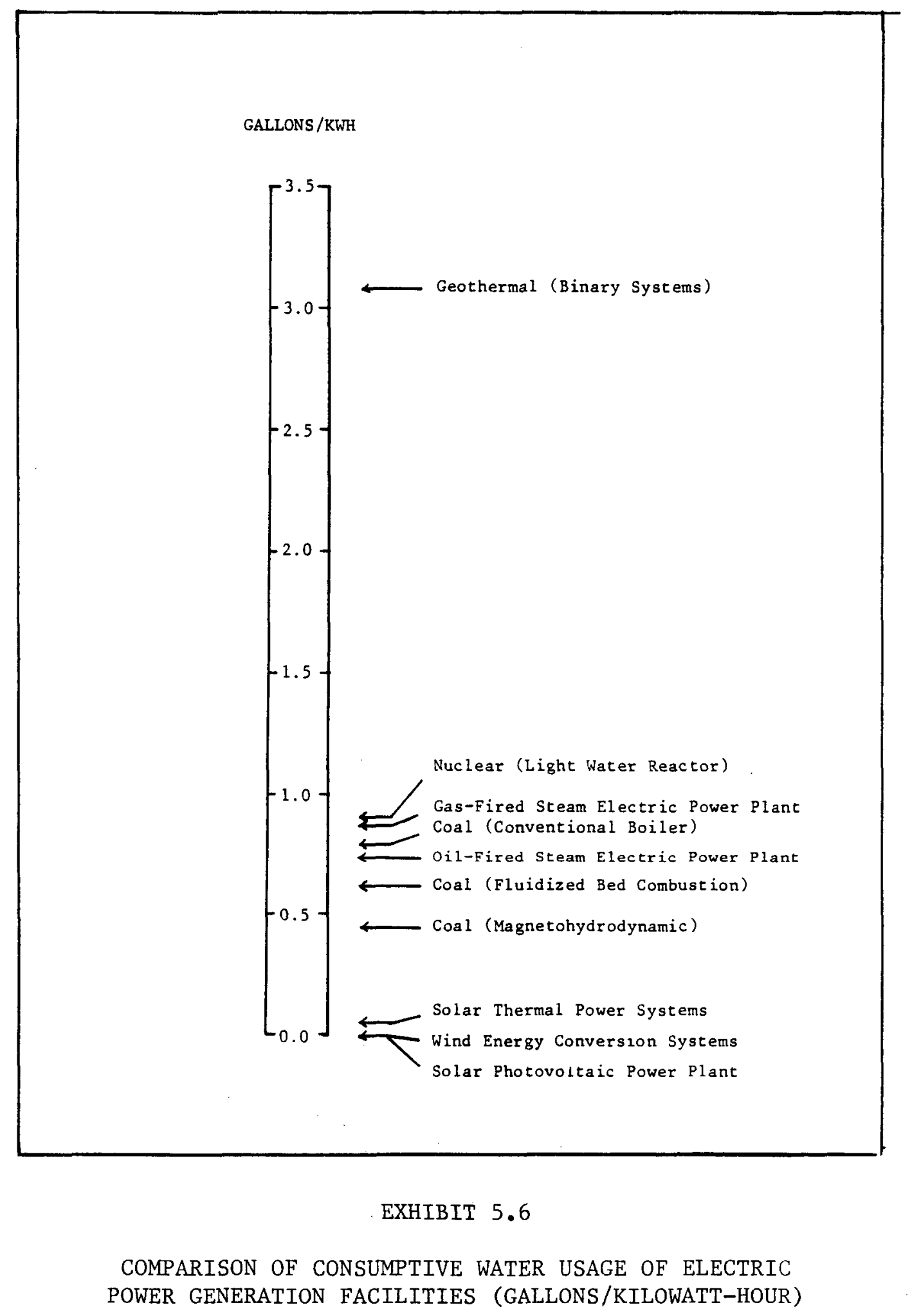

Source: Reference 4 
SUMMARY HIGHLIGHTS OF WATER AVAILABILITY PROBLEMS

IN 34 KNOWN GEOTHERMAL RESOURCE AREAS

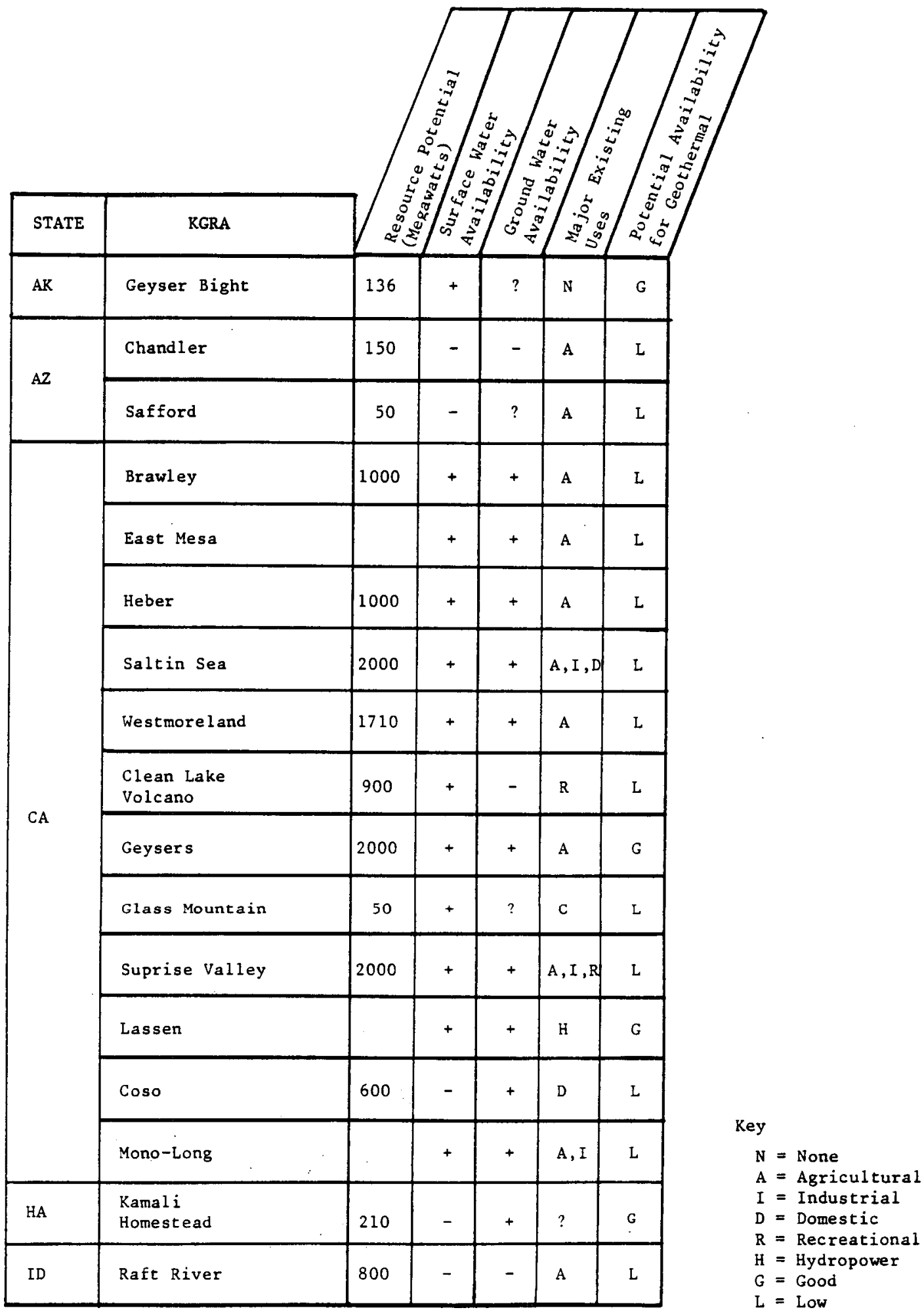

Source: Appendix A 


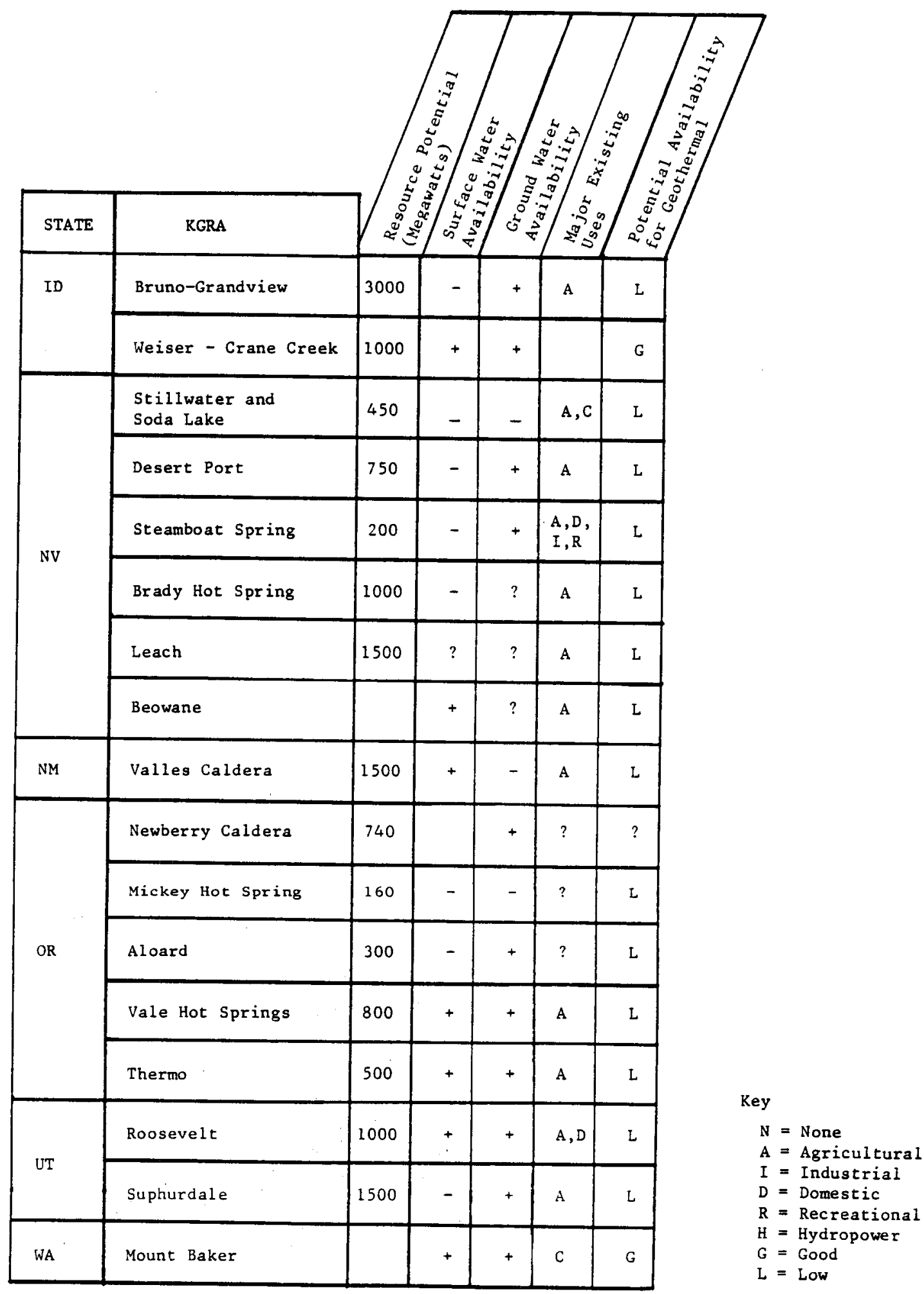


Water use in the western states is generally appropriated. While all water laws and regulations were designed for the equitable distribution of water among various users, water rights and prioritization of water use inadvertantly create a multitude of barriers for new users. In addition, environmental concerns, particularly concerns about stream quality added another dimension to water right acquisition.

In summary, water availability problems associated with geothermal energy development originated from the high water requirements for geothermal power plants, and are complicated by the fact that high-temperature geothermal resources are located in arid and semiarid areas of the nation, creating the need of use allocation systems. Extended development of geothermal energy are exoected to compete with other water users. 
5.4 Why are water availability problems important to geothermal energy development?

The annual average amount of make-up water required for geothermal power plants is estimated to be 13,000 to 26,000 per year per kilowattd. However, seasonal variations, due to electrical energy demand, rainfall pattern, and other water usages place additional stresses on the system. Specifically, for power plants located in arid regions, the summertime peak demand for make-up water could be $50 \%$ higher than the annual average. Likewise, the demand for other uses of water, such as irrigation, industrial and residential uses, are also highest in the summer. Thus, a reliable source of water is important to geothermal development so as to avoid costly shutdowns caused by seasonal water shortages.

Moreover, the problems of water availability cover many facets of technical and institutional issues. The geothermal developer has to be concerned with the adequacy and reliability of water supply, the seasonal variation, the manner in which the water is appropriated, as well as the environmental, social, and economic implication of its development.

Severe limitations to geothermal energy development are expected to occur if water of significant quantity and quality is not available for geothermal energy use. Specifically, geothermal energy development may be limited to vapor-dominated systems or high temperature resources in which flash-steam processes are applicable. In this manner, the steam condensate may be used as make-up water in the geothermal cooling towers. However, certain states and localities 
may require spent geothermal fluids to be injected in order to avoid subsidence. If this is the case, geothermal development may be limited to the use of dry cooling tower systems which add a substantial amount to the cost of the overall operation. 
5.5 What are the typical procedures to the acquisition of water for geothermal energy development?

Shortages of water supplies, whether real or perceived, give rise to greater scrutiny of new and existing users of these scarce resources. The development of geothermal energy, because of its large water requirements will attract public attention. Many jurisdictions have lengthy and complicated procedures for water acquisition for geothermal use. The typical steps 6 involved in obtaining a water right are presented in Exhibit 5.8 and briefly described below:

- Apply to the appropriate state agency, setting forth required data.

- The state instructs the applicant to publish notices to affected and interested parties.

- A hearing is scheduled if objections are filed.

- Pending the result of the hearing, the state agency may approve the permit if water is available and its use is not contrary to the public interest. Most frequently, the applicant will only get "conditional" approval. Typical conditions of approval include:

- Non-interference with existing uses

- Limits on withdrawal rate

- Limitation on use in the event of conflict with preferred uses

- Limitation on places of use, e.g., on-site use only

- Satisfaction of other environmental requirements

- Permit granted may be temporary and needs to be renewed at expiration date.

- Permit application may be considered as part of an overall project and not acted upon until other applications are approved.

In addition, most western states have preferential use of water. Domestic and irrigation use are generally considered as more 
EXHIBIT 5.8

TYPICAL PROCEDURE FOR THE ACQUISITION OF WATER
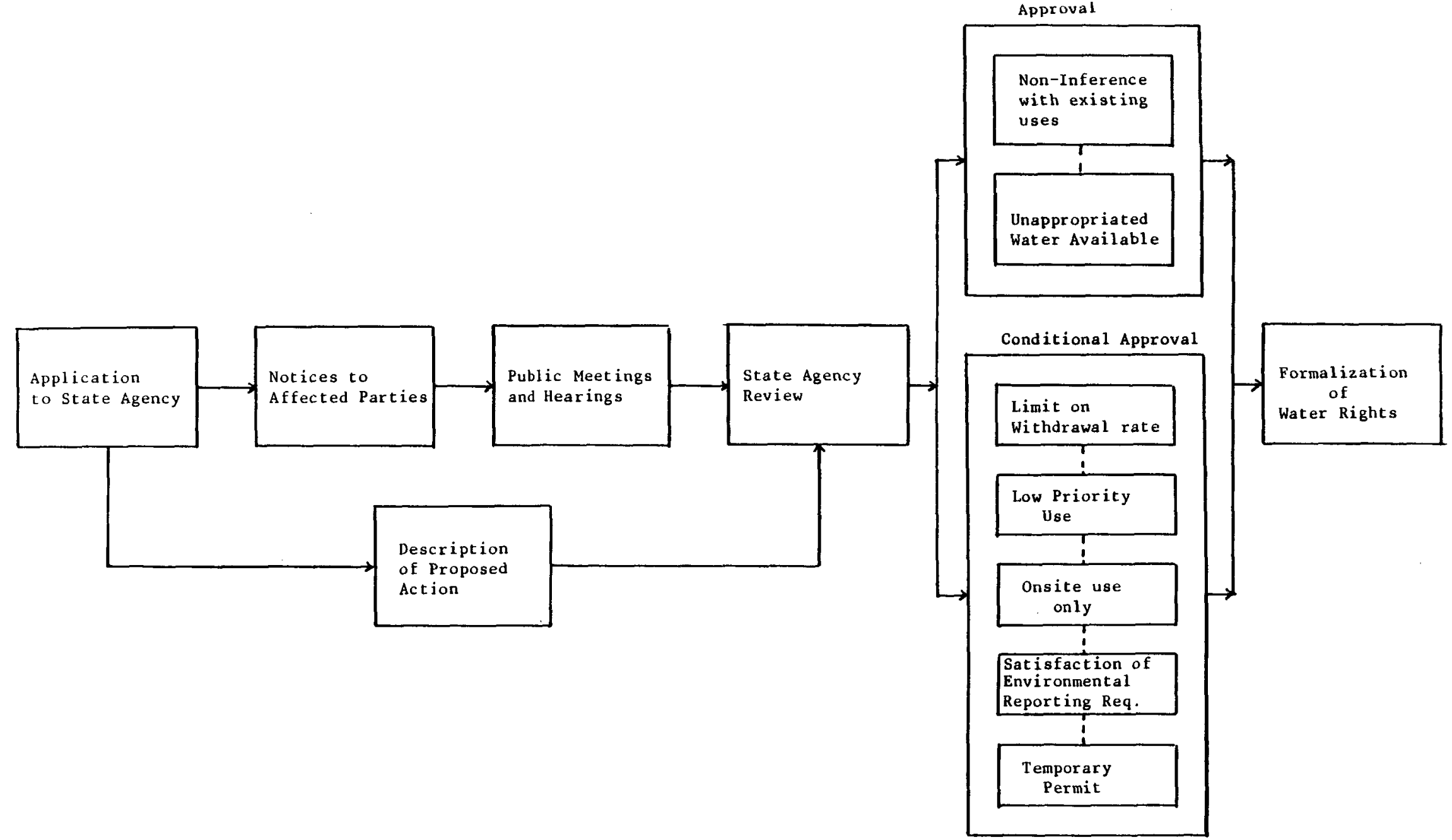
beneficial. In this case, water rights for a power project may be held subordinate to subsequent application which proposes the use of water for domestic and irrigation use. The preferrential use is also reflected upon the cost of obtaining water rights. For most states, the cost of water used for power generation may be significantly higher than the cost of irrigation water. 5 
5.6 What are the possible technical alternatives to reducing water requirements for geothermal power plants?

Since most of the water consumed by a geothermal power plant is used for cooling, a direct approach towards minimizing the water availability problem is through the design of water-conserving heat rejection systems. Cooling towers, particularly wet cooling towers, are most commonly used for heat dissipation in power plants. Other methods of cooling include "once-through" cooling, cooling lakes and ponds, spray ponds and canals, dry cooling tower and its various modifications. The following is a brief description of cooling systems applicable to geothermal power plants:

- "Once-through" Cooling. The once-through cooling system takes water from an abundant source, such as an ocean, large lake or river, and pumps it through the turbine condenser. The heated water is subsequently returned to the source. This system has a high water withdrawal rate. For a 50 MWe geothermal power station with a thermal efficiency of about $15 \%$ and plant capacity of 0.8 , approximately 5.7 billion gallons of cooling water will be required per year. However, since all water will be returned to its source, the amount of water consumed will be negligible. Once through cooling systems, however, have potential severe impact on the aquatic environment. Construction permits for such systems are most difficult to obtain. Further, based on the present knowledge of the most feasible locations for geothermal power stations, it is apparent that sources of water are not likely to be avallable for once-through cooling.

- Cooling Lakes and Ponds. This concept is similar to oncethrough cooling systems except that a man-made reservoir is used for the storage of cooling water. The cost and environmental impacts of using relatively large amounts of land for cooling lakes, the lack of suitable sites and the evaporation and seepage losses from such a water body have generally discouraged construction of lakes solely for the purpose of heat dissipation. If, however, the storage lake can be used for other purposes, such as recreation, water supply or flood control, then the use of the same lake for heat dissipation may be an attractive possibility. The large land area requirements (about 16 acres per MWe) and potentially large water losses deter the use of cooling lakes and ponds for geothermal power stations. 
- Spray Ponds and Canals. Spray ponds and canals spray the water to be cooled into the air, thereby increasing the evaporation rate. Although this system requires only $5 \%$ of the land as that needed by a cooling pond, it does not conserve water and therefore is not a good alternative for geothermal power stations.

- Wet Cooling Towers. These are the most common types of cooling systems used by geothermal, fossil, and nuclear fuel power plants. They operate on the principle that water acting as the heat transfer fluid, give up heat to atmospheric air and is thus cooled. The water is also recirculated through the system affording economic operation of the process. In the cooling process, a small portion ( 1 to $3 \%$ ) of the condenser circulating water is evaporated. However, because of the large quantities of cooling water circulating through the tower, water loss through evaporation becomes a significant portion of water consumption. The air stream usually leaves the cooling tower at or very close to saturation conditions, creating fogging and tower-induced icing.

- Dry Cooling Towers. There are two basic types of dry cooling systems for power plant or process cooling. One types uses air-cooled steam surface condenser as the means for transferring the rejected heat to the atmospheric cooling air. The other uses an air-cooled heat exchanger for the same purpose. Water and ammonia are the most common heat transfer fluids used to convey the heat from the condenser to the aircooled coils. The heat transfer per unit mass of air moving through the tower is small relative to the towers that evaporates water, and consequently, surface area requirements are higher, leading to high capital costs for dry cooling towers. In addition, performance is sensitive to the ambient temperature, humidity, and wind velocity. Dry cooling towers are the least efficient of the cooling systems, and are more costly than conventional wet cooling towers of the same capacity. Research and development in this area may bring down the capital cost of dry cooling towers making it more competitive with the conventional wet cooling systems.

- Wet/Dry Cooling. Towers. The combination of evaporative and non-evaporative cooling tower is arranged so that the water to be cooled first passes through a non-evaporative cooling stage and then leaving this section by force of gravity to the cooling stage. These cooling towers are used in order to take advantage of the lower heat-sink temperature attainable with evaporative cooling when an adequate water supply is available, and to allow the plant to continue to operate, at reduced efficiency when water for cooling is in short supply. On an annual basis, this concept permits significant savings in the amount of water needed for cooling tower make-up. The combination of the tower types into one structure and sharing air-moving equipment, also results in some savings. However, 
wet/dry cooling systems still cost two to three times more than conventional wet cooling towers of the same capacity.

- Deluge Cooling of Dry Towers. The capacity of a dry cooling coil can be increased by evaporating water on the outside surface. Hence, spraying water onto the coils may be sufficient to carry the plant through the peak load periods. The amount of water lost by evaporation is also small relative to the losses from conventional wet cooling towers. However, a major problem with this system is that evaporating water leaves behind deposits of dissolved solids which foul the coil surfaces.

- Phased Cooling. For power stations that have significant diurnal differences in cooling capacity, water consumption may be reduced by storing a portion of the warmed circulated water for nightime heat dissipation. Depending on the availability of land, construction cost for storage basins and evaporation losses from the storage basins, phased cooling may be a practical means of reducing water consumption.

Exhibit 5.9 summarizes the advantages, disadvantages, and other germane features of the different cooling systems. Technical solutions are avallable for water conservation. An important consideration, however, is to make these options more cost effective. The wet/dry cooling technique appears to be a good compromise between technological readiness and cost. 
EXHIBIT 5.9

COMPARISON OF DIFFERENT COOLING SYSTEMS THAT HAVE

POTENTIAL APPLICATION TO GEOTHERMAL POWER PLANTS

\begin{tabular}{|c|c|c|c|c|c|}
\hline $\begin{array}{l}\text { Cooling } \\
\text { Systems }\end{array}$ & $\begin{array}{l}\text { Cooling } \\
\text { Mechanism }\end{array}$ & Advantages & Disadvantages & $\begin{array}{l}\text { Estimated } \\
\text { Cost } \\
\text { per KW }\end{array}$ & $\begin{array}{l}\text { Applicable to } \\
\text { Geothermal Power } \\
\text { Plants }\end{array}$ \\
\hline $\begin{array}{l}\text { Once through } \\
\text { cooling }\end{array}$ & - Convective & $\begin{array}{l}\text {-Simple Design } \\
\text { - Inexpensive }\end{array}$ & $\begin{array}{l}\text { - Thermal Pollution } \\
\text { Damage to Aquator } \\
\text { Life }\end{array}$ & $\$ 15-\$ 30-$ & - Unlikely \\
\hline $\begin{array}{l}\text { Cooling Lakes } \\
\text { and Pond }\end{array}$ & $\begin{array}{l}\text { - Evaporative } \\
\text { - Radiative }\end{array}$ & $\begin{array}{l}\text { - Multiple Use } \\
\text { (recreation, storage) }\end{array}$ & $\begin{array}{l}\text { - Large Land } \\
\text { Requirement 10-16 } \\
\text { acres/MWE } \\
\text { - Water Loss Due to } \\
\text { Seepage }\end{array}$ & $\$ 100$ & -Unlikely \\
\hline $\begin{array}{l}\text { Spray Ponds } \\
\text { and Canals }\end{array}$ & $\begin{array}{l}\text { - Evaporative } \\
\text { - Convective }\end{array}$ & $\begin{array}{l}\text { - Small Land } \\
\text { Requirement Relative } \\
\text { to Ponds } \\
\text { - Low Maintenance }\end{array}$ & $\begin{array}{l}\text { - High Drift Rate } \\
\text { - Large Water } \\
\text { - Consumption } \\
\text { Potential Damage to } \\
\text { vegetation due to } \\
\text { salinity }\end{array}$ & & -Unlikely \\
\hline $\begin{array}{l}\text { Wet Cooling } \\
\text { Towers }\end{array}$ & - Evaporative & $\begin{array}{l}\text { - Small Land } \\
\text { Requir ement }\end{array}$ & $\begin{array}{l}\text { - High Water } \\
\text { Consumption } \\
\text { - Fogging }\end{array}$ & $\$ 10-\$ 20$ & $\begin{array}{l}\text { - Being Used } \\
\text { Now }\end{array}$ \\
\hline $\begin{array}{l}\text { Dry Cooling } \\
\text { Towers }\end{array}$ & - Conventive & $\begin{array}{l}\text { - Very Low Water } \\
\text { Consumption }\end{array}$ & $\begin{array}{l}\text {-High Capital Cost } \\
\text { - Sensitive to Wind } \\
\text { and Thermal } \\
\text { Inversion }\end{array}$ & $\$ 50-\$ 100$ & $\begin{array}{l}\text { - Unlikely } \\
\text { because of } \\
\text { cost }\end{array}$ \\
\hline $\begin{array}{l}\text { Wet/Dry } \\
\text { Cooling }\end{array}$ & $\begin{array}{l}\text { - Conventive } \\
\text { - Evaporative }\end{array}$ & $\begin{array}{l}\text { - Reduce Water } \\
\text { Consumption } \\
\text { - Ideal for Handling } \\
\text { Peak Load }\end{array}$ & $\begin{array}{l}\text { - Still Relatively } \\
\text { Expensive }\end{array}$ & $\begin{array}{l}\$ 10-\$ 100 \\
\text { Depends on } \\
\text { Wet } / \text { Dry } \\
\text { Cooling } \\
\text { Ratio }\end{array}$ & $\begin{array}{l}\text { - Likely; R\&D } \\
\text { Needed to } \\
\text { Bring Down } \\
\text { Cost }\end{array}$ \\
\hline $\begin{array}{l}\text { Deluge } \\
\text { Cooling }\end{array}$ & - Evaporative & $\begin{array}{l}\text { - Increase Efficiency } \\
\text { without major } \\
\text { changes }\end{array}$ & $\begin{array}{l}\text { - Fouling of Cooling } \\
\text { Coil Surfaces }\end{array}$ & & $\begin{array}{l}\text { - A Feasible } \\
\text { Option }\end{array}$ \\
\hline $\begin{array}{l}\text { Phased } \\
\text { Cooling }\end{array}$ & - Evaporative & $\begin{array}{l}\text { - Increase Overali } \\
\text { Efficiency of the } \\
\text { System }\end{array}$ & $\begin{array}{l}\text {-Require Large } \\
\text { Storage Ponds }\end{array}$ & $\begin{array}{l}\$ 10-\$ 20 \\
\text { P1us Cost } \\
\text { of Storage } \\
\text { Pond }\end{array}$ & $\begin{array}{l}\text { - Feasible if } \\
\text { Land Available }\end{array}$ \\
\hline
\end{tabular}


5.7 What are the unconventional solutions?

Another aspect in reducing the water consumption of geothermal power plant is by changing its operation modes. An alternative is the use of a variable or a "floating" power plant. Contrary to conventional power plants which are designed for constant power output, a variable power plant changes its output according to the capacity of the heat rejection system. The advantages of this concept are greatest in locations where there are wide variations in the sink temperature due to diurnal and seasonal changes. The power output of the plant can, therefore, vary with the heat dissipation capacity. However, a disadvantage of this system is that the peak load requirement may not coincide with the heat dissipation capacity. In addition, there is substantial penality in capital cost in having equipment installed that is at times only partially loaded, although this may be offset by the reduction in cost of cooling equipment.

The variable power plant concept favors plants with moderate thermal efficiencies, where the cost of cooling installation became a significant portion of the total plant cost. Thus geothermal power plants, with their inherent low thermal efficiency are likely candidates for the variable capacity concept.

Other concepts in reducing the water requirement for geothermal power plants is through the use of industrial co-generation and district heating.9 Both these systems are essentially waste heat utilization systems which indirectly reduce the water requirement by decreasing the heat dissipation requirements. Combining generation of electricity with production of industrial steam could substantially improve energy use efficiency. In district heating systems, hot 
water or steam, is conveyed by a network of insulated pipes from a central plant. The piping may be efther a single once-through system or a double closed loop arrangement returning cooled water or condensed steam to the central power station. The recycling of cooled water would therefore greatly reduce the cooling tower make-up water requirements to the extent that the use of cooling towers may be completely eliminated.

However, these waste heat utilization systems are difficult to implement. For co-generation, applicability is limited because industrial needs do not necessarily match those of existing or proposed geothermal power plants. The geothermal developer must find a nearby industrial plant with steam requirements equal to the output of the operating units. Since the economy of a district heating system is a function of size, the planning of the entire system, including future expansions, is extremely important.

There are numerous technical and economic uncertainties regarding the waste heat utilization systems. Fundamental to these questions are cost allocation and ownership issues. Others include assurance of markets, evolution of systems to match market changes and requirements for acceptance of services by private entities. 
5.8 What are the legal/institutional constraints of the water availability problems?

The development of geothermal energy faces a variety of waterrelated legal/institutional constraints that are inadvertently imposed through a number of water laws, environmental protection laws and facility siting laws. The most prevalent themes underlying these laws are in the protection of "public interest" and the concept of "beneficial use". Public interest represents a multiplicity of competing values, including economic productivity, environmental quality, ecological integrity and socio-cultural equity. Water acquisition and use often depend upon the degree of competition and conflicts surrounding the resource. In addition, the imperfect integration of the legal system with the natural system often lead to conflicts and contradiction among different water laws. For many hydrological systems, there may be communication between groundwater and surface water to the extent that the extensive withdrawal and use of one system often affect the other. However, most states have segregated laws governing the use of groundwater and surface water. Exhibit 5.10 is a simplified diagram illustrating the interface between the natural system and legal system.

Water use and acquisition is generally controlled by state laws. The surface water legal systems can be conveniently classified into that of riparian rights and appropriation rights 6 which are briefly described below:

- Riparian rights entitles the owner of the land, adjacent to which or upon which a:stream flows, to the use of the water for purposes beneficial to his or her land. A limitation is that the owner cannot impart the natural flow of the stream by diminishing its quantity or quality for downstream owners. 
EXHIBIT 5.10

INTERFACE BETWEEN THE NATURAL SYSTEM AND LEGAL SYSTEM

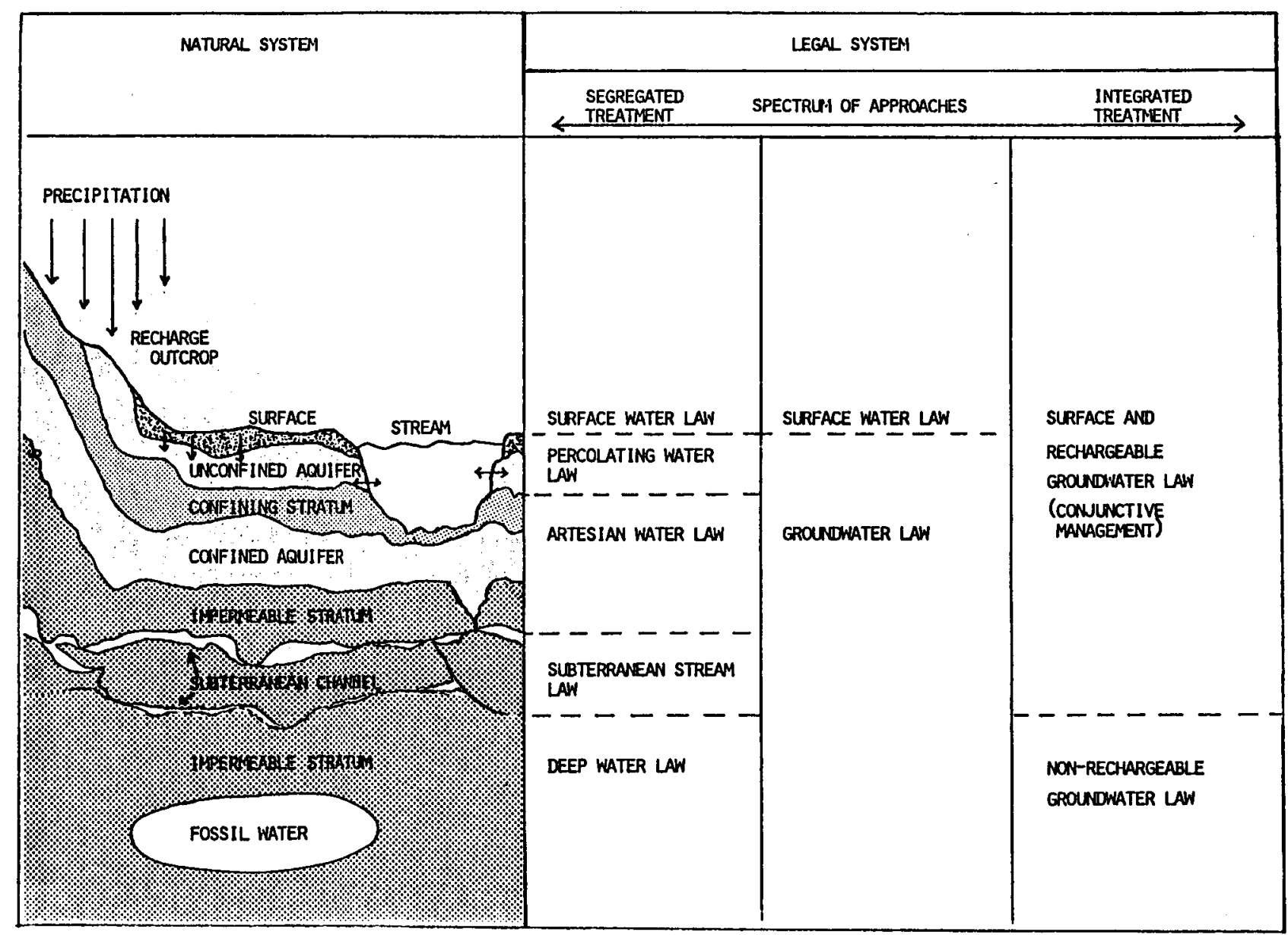


- Appropriation rights disregard land ownership. A person could withdraw water and apply it to a beneficial use only upon approval of appropriate authority. This system generally ensures that economically valuable activities could persist despite their physical removal from the source of water supply.

Most western states reject the riparian approach primarily because farming and mining are the principal forces of deelopment. Both activities rely heavily on water diverted from its natural banks. In addition, arid conditions promote the adoptation of the appropriation doctrine. Exhibit 5.11 compares the major features of the riparian and appropriation approach. Exhibit 5.12 depicts the distribution of these water use legal system, based on riparian, appropriation or some combinations thereof.

For groundwater, the legal systems are more complex. They can be classified into four principal categories as described below:

- Absolute Ownership. Overlying land owner can withdraw groundwater without liability for damage to any other persons using the same groundwater sources.

- Reasonable Use. Overlying land owners have equal rights to the groundwater and are limited to nonwasteful users.

- Correlative Rights. Rights are allocated proportionate to the extent of overlying land ownership.

- Prior Appropriation. Varying degrees of public control and administration are asserted over groundwater under this system, with the private right of use being granted by permit application systems.

As with surface water use, prior appropriation is most prevalent in the western states. The institutional structure for the protection of groundwater varies from state to state depending on the function to be served. Functions related to groundwater management generally include: 


\begin{tabular}{|c|c|}
\hline Riparian Rights & Appropriation Rights \\
\hline $\begin{array}{l}\text { - "Private waters" - right to } \\
\text { use held by owners of riparian } \\
\text { land (land adjacent to stream } \\
\text { flow). }\end{array}$ & $\begin{array}{l}\text { - Any person, regardless of land } \\
\text { ownership, may withdraw water } \\
\text { and apply it to a beneficial use. }\end{array}$ \\
\hline $\begin{array}{l}\text { - Entitles owner to use water } \\
\text { for beneficial purposes on } \\
\text { his/her own land. }\end{array}$ & $\begin{array}{l}\text { - Ensure that economically valuable } \\
\text { activities could persist. }\end{array}$ \\
\hline - May not impair "natural flow". & $\begin{array}{l}\text { - Require permit, before water may } \\
\text { be withdrawn, from a designated } \\
\text { state agency. }\end{array}$ \\
\hline $\begin{array}{l}\text { - Rights are co-equal. In time of } \\
\text { shortage, everyone cuts back on } \\
\text { use. No priorities are given. }\end{array}$ & $\begin{array}{l}\text { - Beneficial use is a cardinal } \\
\text { principal which includes all } \\
\text { economically valuable uses } \\
\text { related to domestic, municipal, } \\
\text { irrigation, mining, and indus- } \\
\text { trial purposes. }\end{array}$ \\
\hline & $\begin{array}{l}\text { - Prioroty uses receive delivery } \\
\text { in times of scarcity. }\end{array}$ \\
\hline
\end{tabular}

EXHIBIT 5.11

SOME OF THE MAJOR CHARACTERISTICS OF

SURFACE WATER LEGAL SYSTEMS 


\section{EXHIBIT 5.12}

SURFACE WATER LEGAL SYSTEMS IN THE U.S.

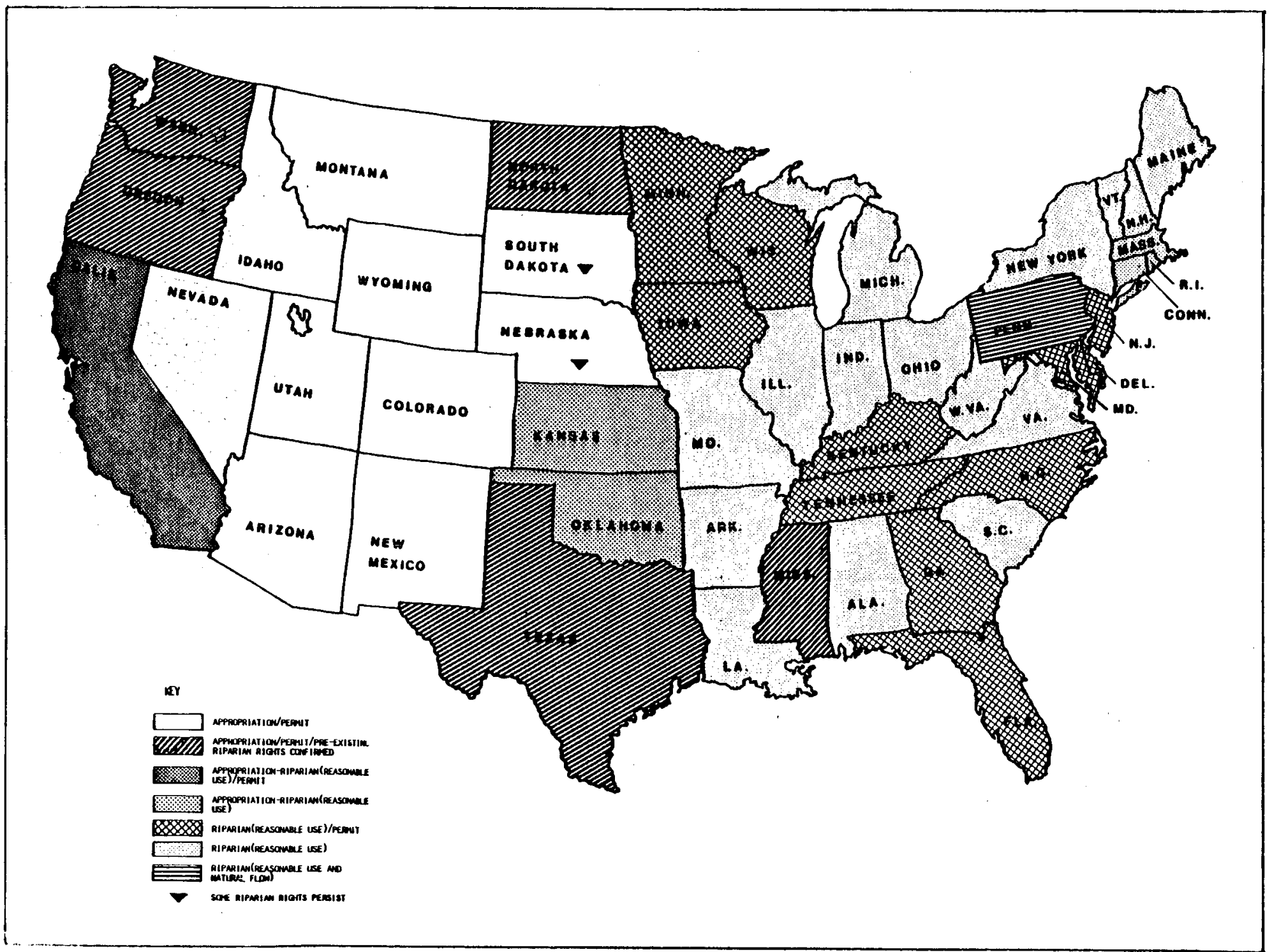


- Permit administration

- Policing of water distribution

- Transfer administration

- Water rights adjudication

- Water quality control

The institutional structure at the state level includes offices of state engineers, departments of water resources, water commissions and water boards. At the local level, special districts and county departments and agencies are generally involved in groundwater regulation and management. More detailed discussions on the state and local regulations are discussed in Section 5.10.

Although most legal/institutional constraints on water acquisition often result from the application of state laws, the federal government has a "reserved" right to surface and groundwater associated with land it withdraws from the public domain and reserves for specific federal purposes. This system of water rights is superimposed on the riparian and appropriation systems. Numerous federal water quality statutes create further constraints on water uses and acquisition. Some of the more common legal/institutional problems and their implication on geothermal energy development are listed in Exhibit 5.13. In addition, numerous constraints that are legislative in nature may impinge on the water acquisition stage of energy development; for example environmental reporting, as required by the National Environmental Policy Act (NEPA) and its state and local counterparts, compels the disclosure of proposed water sources and the examination of possible alternatives and anticipated impacts. Facility siting, coastal management and local land use programs also 
Exhibit 5.13

SOME COMMON LEGAL/INSTITUTIONAL CONSTRAINTS

ASSOCIATED WITH GEOTHERMAL DEVELOPMENT

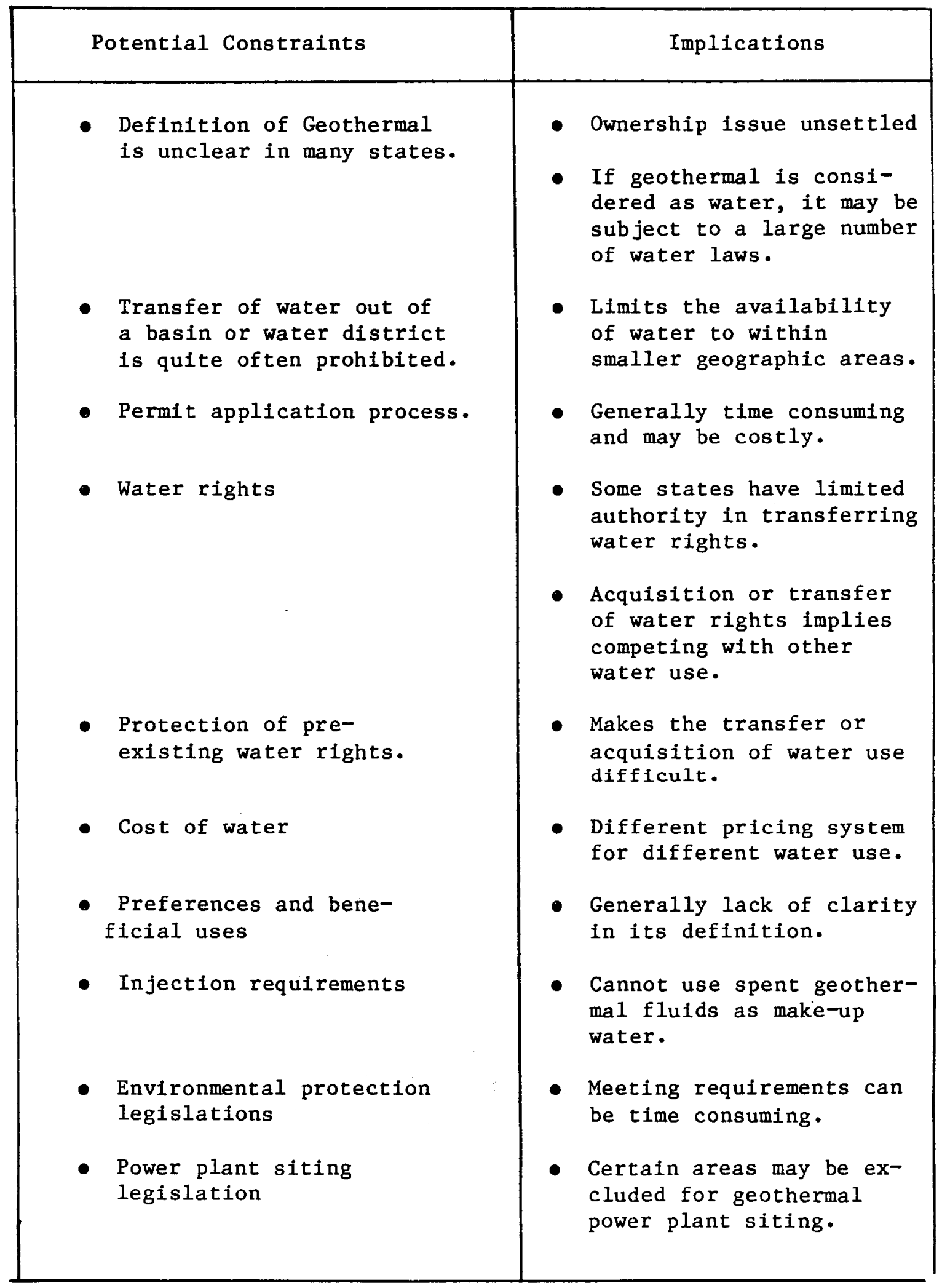


promote the public review of resource commitment, including water required for large-scale energy development projects.

Some legal/institutional constraints are the result of uncertainties in the laws defining rights and governing uses, while other result in some conflicting requirements among different laws and statutes. The geothermal developers must, therefore, be prepared to take calculated rights, or to seek legal clarification through litigation or legislation. Im most settings, the types of legal/ institutional constraints in water acquisition can be overcome through advanced planning and coordination with the proper authorities. 
5.9 What are the Federal Regulations Affecting Water Resources and Use Allocation?

Before acquiring the rights to use water for a geothermal power plant the developer must meet a variety of federal regulations affecting water resources. This is particularly true for geothermal development occurring on federal lands. Specifically, the federal government has a "reserved" right to surface and groundwater associated with land it withdraws from the public domain and reserves for a specific federal purpose. Depending on the scope of the project, the federal government may require a developer to file an Environmental Impact Statement (EIS) for any activities conducted on federal land which may have a significant impact on the environment. In addition to the National Environmental Policy Act (NEPA) which requires federal agencies to conduct a thorough EIS, there are others that require federal leases, permits, and licenses.

For geothermal development occurring on non-federal lands, the developer still has to abide by a number of water quality and pollution control statutes designed to protect the water quality of the nation. The Clean Water Act and Safe Drinking Water Act are the major regulatory instruments used to control the quality and use of water resources. Exhibit 5.14 identifies federal legislation affecting water resources for geothermal development and use.

Each of these Federal acts provides direct or indirect control and protection of water resources in environmentally sensitive areas. The Geothermal Steam Act is considered a blanket type environmental protection legislation and requires geothermal lesses to comply with all Federal, state, and local environmental standards. Section 13B 
Exhibit 5.14

MAJOR FEDERAL LEGISLATIONS AFFECTING WATER RESOURCES FOR GEOTHERMAL DEVELOPMENT

- Federal Water Pollution Control Act, Clean Water Act of 1972, P.L. 93-500, amended P.L. 95-217.

- Safe Drinking Water Act, P.L. 93-523 amended P.L. 95-190.

- Resource Conservation and Recovery Act of 1976, P.L. 94580, amended P.L. 96-482.

- National Environmental Policy Act of 1969, P.L. 91-190.

- Federa1 Non-nuclear Energy Research and Development Act of 1974, P.L. 93-577.

- Geothermal Steam Act of 1970, P.L. 91-581 and related Geothermal Resource Operation Orders (particularly GRO Order 4).

- Geothermal Energy Research and Development Act of 1974, P.L. 93-410.

- Marine Protection Research and Sanctuaries Act of 1972, P.L. 92-532.

- Coastal Zone Management Act of 1972, P.L. 92-583, amended 1976, P.L. 94-37.

- National Wild and Scenic Rivers Act of 1976, P.L. 94-579.

- Toxic Substances Control Act of 1976, P.L. 94-469.

- Fish and Wildlife Coordination Act.

- Federal Land Policy Management Act of 1976.

- Endangered Species Act of 1973, P.L. 93-205.

- Wilderness Act of 1964, P.L. 88-577. 
and $\mathrm{C}$ of the Non-nuclear Energy Research and Development Act requires water assessments be conducted for all energy development activities of Federal lands. Sections 2(12), 104, 105(a)(1), and 301 of the Geothermal Energy R\&D Act require a developer to meet all environmental standards as a specific goal of the program and calls for the development of environmentally acceptable processes.

The two major control tools provided by the Clean Water Act to control pollution are the Effluent Guidelines (Section 301, 304, 307) and the NPDES Permit Program (Part 125, Section 402) which incorporates the limitations of the Effluent Guidelines. The Safe Drinking Water Act, Underground Injection Control (UIC) Regulations provides protection for all groundwater resources throughout all phases of a geothermal development project. The Resource Conservation and Recovery Act (RCRA) has a potential bearing on the quantity and quality of groundwater available for energy use. One of the Act's expressed goal is to preserve and enhance water quality, and as such, it will operate to make more groundwater usable.

In most instances, federal statutes identified in Exhibit 5.14 may restrict the energy-related acquisition of water insofar as they make certain sources available for drinking water and that use is persued. In addition, reducing the contamination of surface and groundwater may make these water supply sources attractive to other uses, such as irrigation, and drinking water supply, consequently creating more competition for other water uses. The issue of water quality and quantity is regional in nature. Thus, many federal acts mandate individual states to determine their own pollution control 
mechanisms including the enforcement of certain federal environmental regulations. Different mechanisms have been developed to comply with the array of requirements and standards set by these legislative acts. Included are environmental quality standards compliances, permit applications, environmental reviews, and site-specific environmental impact statements. 
5.10 What are the state and local regulations affecting water resource use and allocation?

Most of the institutional constraints surrounding water rights are expressed in laws dealing directly with water, environmental protection and control, and power plant siting. Exhibit 5.15 identifies state water laws pertinent to geothermal development.10 These laws provide a general indication of the regulatory environment which a developer must deal with in order to obtain water for a geothermal plant.

State legal constraints could be a significant issue concerning the availability of water for geothermal development. Exhibit 5.16 compares the water use allocation system with the Know Geothermal Resource Areas (KGRA). For most states in which high-temperature resources are known to exist, water uses are appropriated. Exhibit 5.17 summarizes the major legislative elements and their constaint on water acquisition, in the Western States where geothermal energy development is expected to be predominent.11 The following is a brief description of the implications of state legal constraints potentially applicable to geothermal development.

- Groundwater Mining. Prohibits against withdrawals from rechargeable aquifer at specified rates. Uncertainty regarding mining of such aquifer may exist.

- Offsite Use. Generally, preferences are given for overlying use. Transwatershed export or interstate transport is either restricted or prohibited.

- Protection of Surface Water or Land Rights. Prohibits or restricts the withdrawal of. "tributary" groundwater which may adversely affect surface water right holders. Limits on rate and volume of pumping to control land subsidence.

- Protection of Groundwater Rights. Prohibits or restricts against reduction in pressure and increase in depth to water table. 


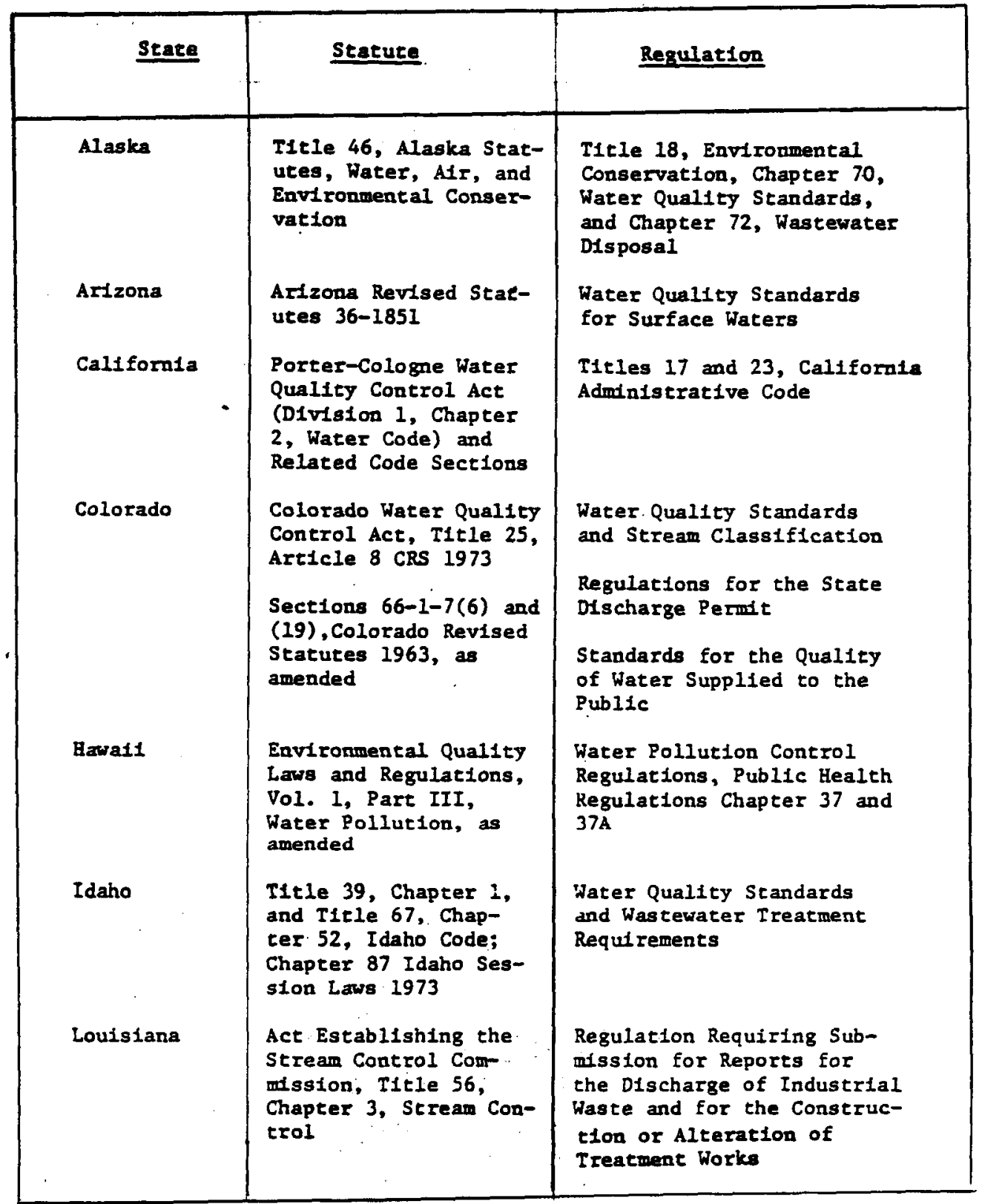

$$
\text { EXHIBIT } 5.15
$$

STATE LAWS AND REGULATIONS PERTAINING TO

GEOTHERMAL ENERGY DEVELOPMENT 


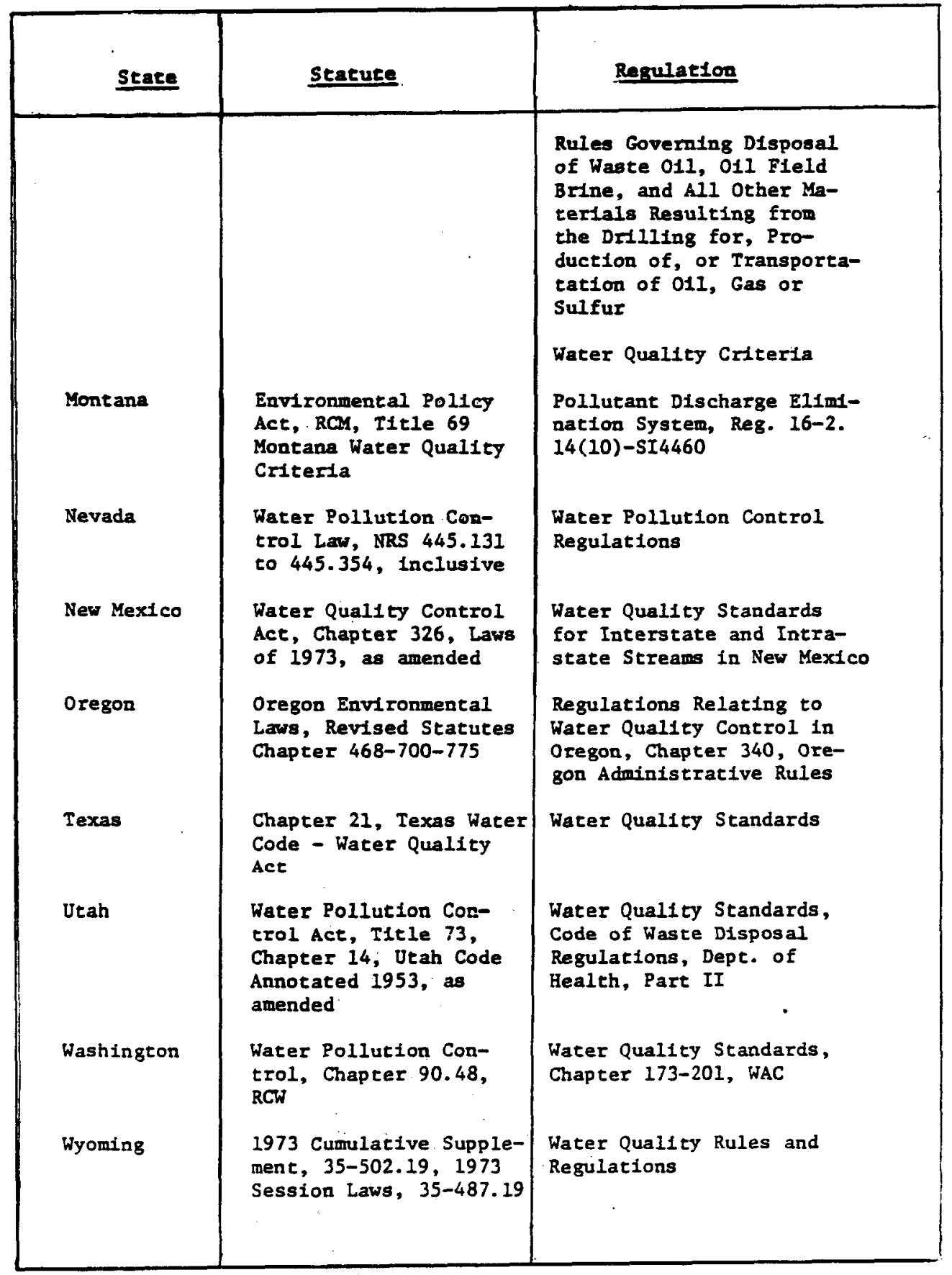

EXHIBIT 5.15 (Concluded)

STATE LAWS AND REGULATIONS PERTAINING TO

GEOTHERMAL ENERGY DEVELOPMENT 

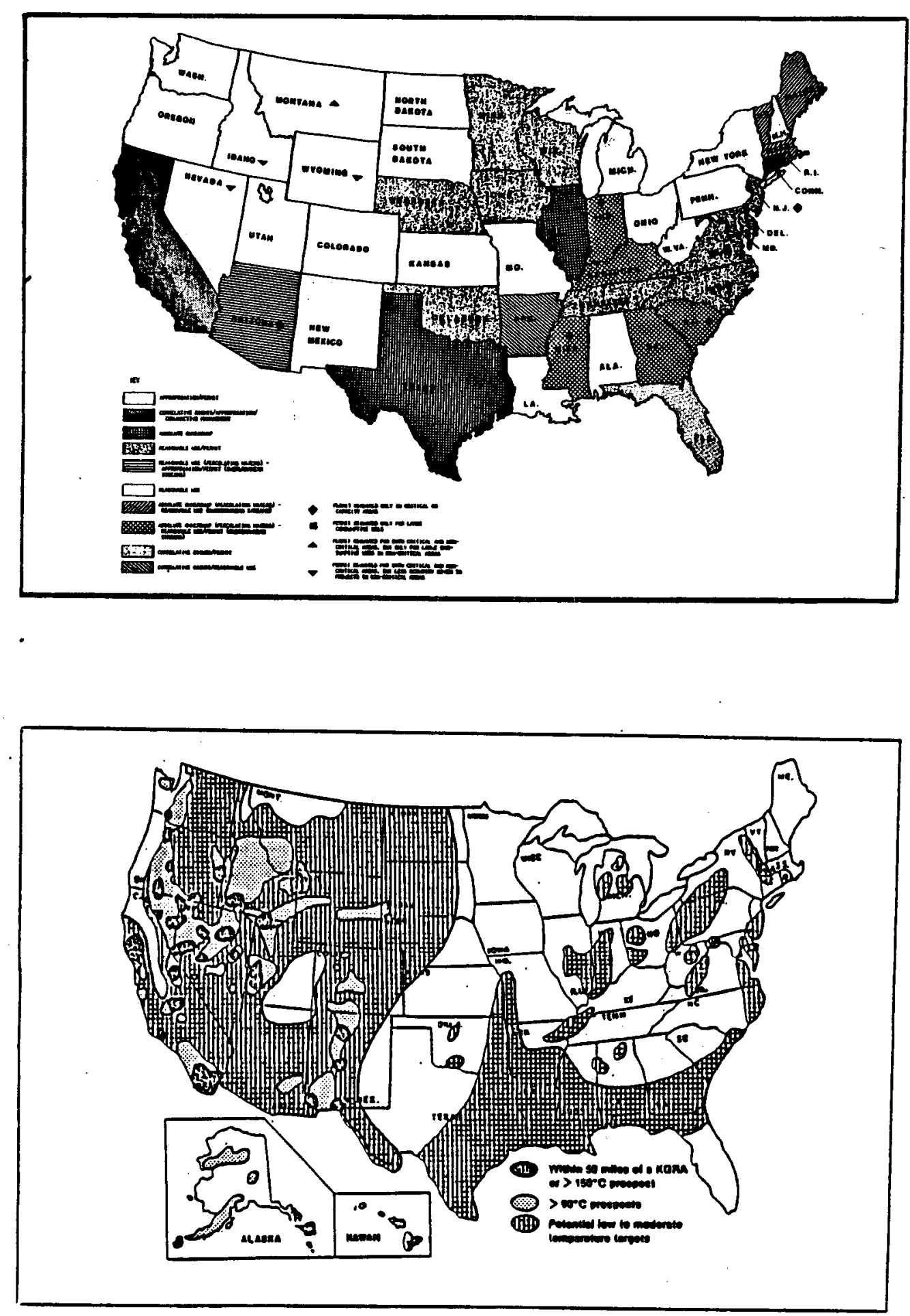

EXHIBIT 5.16

COMPARISON OF WATER USE ALLOCATION SYSTEM WITH KNOWN GEOTHERMAL RESOURCE AREAS 


\begin{tabular}{|c|c|}
\hline LEGISLATIVE ELEMENTS & LEGAL CONSTRAINTS \\
\hline $\begin{array}{l}\text { Arizona } \\
\text { - no formal prior appropriation } \\
\text { - designation of boundaries for } \\
\text { groundwater basin s sub-- } \\
\text { basins } \\
\text { - mine dewatering regulated by } \\
\text { permit }\end{array}$ & $\begin{array}{l}\text { Groundwater mining: Degignation of boundaries for } \\
\text { groundwater basins } \\
\text { Offsite use: Restrictions apply to "critical } \\
\text { groundwater areas" } \\
\text { Protection of surface water and land rights: no } \\
\text { detriment to existing uses (permits could be } \\
\text { denied where proposed use would be detrimental } \\
\text { to surface interests) } \\
\text { Protection of groundwater rights: Groundwater } \\
\text { users protected if someone transports water beyond } \\
\text { overlying land } \\
\text { Beneficial use, preference and definitions: n/a } \\
\text { Diligence: No diligence requirements - common-law } \\
\text { groundwater doctrines prevail }\end{array}$ \\
\hline $\begin{array}{l}\text { California } \\
\text { - no statutory scheme for the } \\
\text { general control of groundwater } \\
\text { - each user has equal right } \\
\text { - Dept. of Water Resources exer- } \\
\text { cises considerable jurisdiction } \\
\text { over groundwater } \\
\text { - Authorizes the creation of } \\
\text { groundwater management } \\
\text { diatricts } \\
\text { - Water Resource Control Board } \\
\text { also initiates adjudiciation } \\
\text { to prevent injury to ground- } \\
\text { water supplies }\end{array}$ & $\begin{array}{l}\text { Groundwater mining: Prohibited } \\
\text { offsite use: Surplus water appropriated for } \\
\text { offsite use } \\
\text { Protection of surface water and land rights: No } \\
\text { detriment to existing uses } \\
\text { Protection of groundwater rights: other water users } \\
\text { receive considerably more protection in California, } \\
\text { under the corelative rights doctrine. } \\
\text { Beneficial use, preference and definitions: a/a } \\
\text { Diligence: No diligence requirement - common-law } \\
\text { groundwater doctrines prevail }\end{array}$ \\
\hline $\begin{array}{l}\text { Colorado } \\
\text { - State engineer has general } \\
\text { supervisory control over } \\
\text { surface and groundwater } \\
\text { - two categories of groundwater } \\
\text { recognized : (i) designated } \\
\text { groundwater; (ii) groundwater } \\
\text { tributary to a stream } \\
\text { - Colorado Grcund Water. } \\
\text { Commission designates and } \\
\text { controls groundwater basins, } \\
\text { and regulates withdrawal } \\
\text { - both designated groundwater } \\
\text { and tributary groundwater } \\
\text { appropriated by permit }\end{array}$ & $\begin{array}{l}\text { Groundwater Mining: (tributary) no restrictions, } \\
\text { (designated basins) prohibited. Controlled depletion } \\
\text { in nonrecharageable basins. } \\
\text { offsite use: No exports out of state. Local } \\
\text { districts may prohibit exports of designated ground- } \\
\text { water out of basin } \\
\text { Protection of surface water and land rights: no } \\
\text { detriment to existing uses } \\
\text { Protection of groundwater rights: no detriment to } \\
\text { existing uses (no unreasonable reduction in pumping } \\
\text { and levels of existing uses), no mining of recharge- } \\
\text { able designated basins } \\
\text { Beneficial uses, preferences, and definitions: } \\
\text { domestic and agriculture preferred over energy and } \\
\text { other uses } \\
\text { Diligence: } 1 \text { year to complete appropriation. } \\
\text { Liberal extensions. }\end{array}$ \\
\hline
\end{tabular}




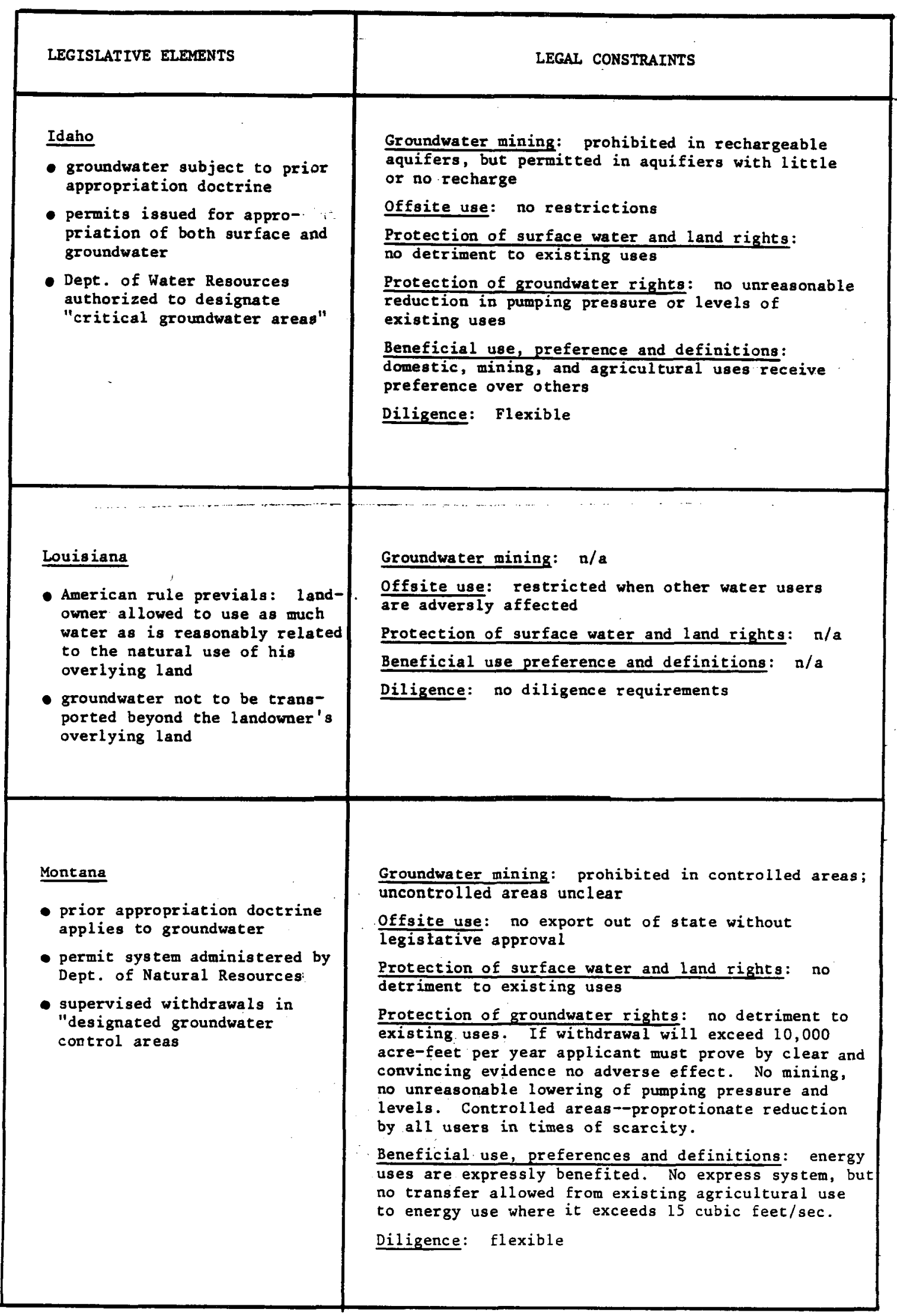




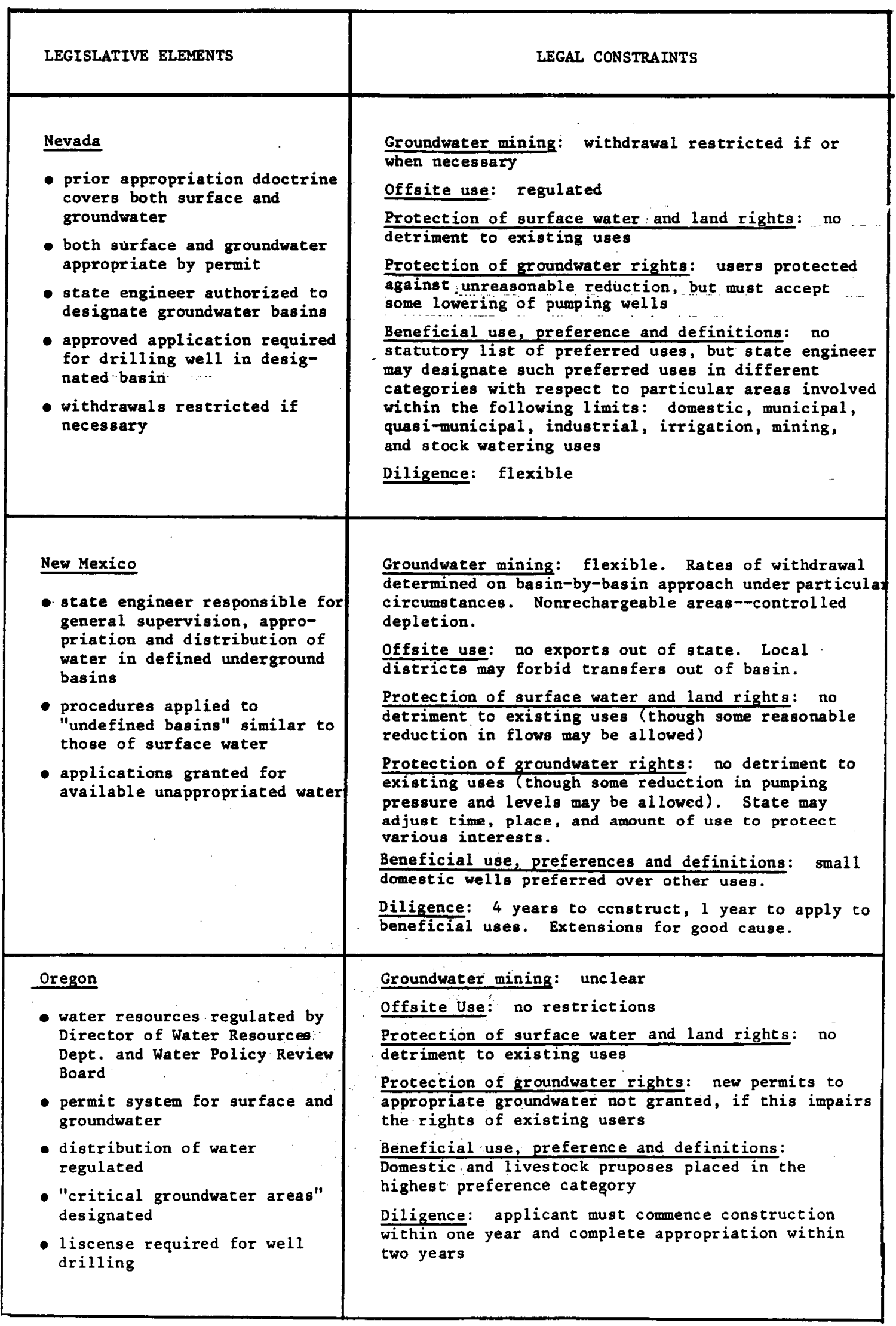




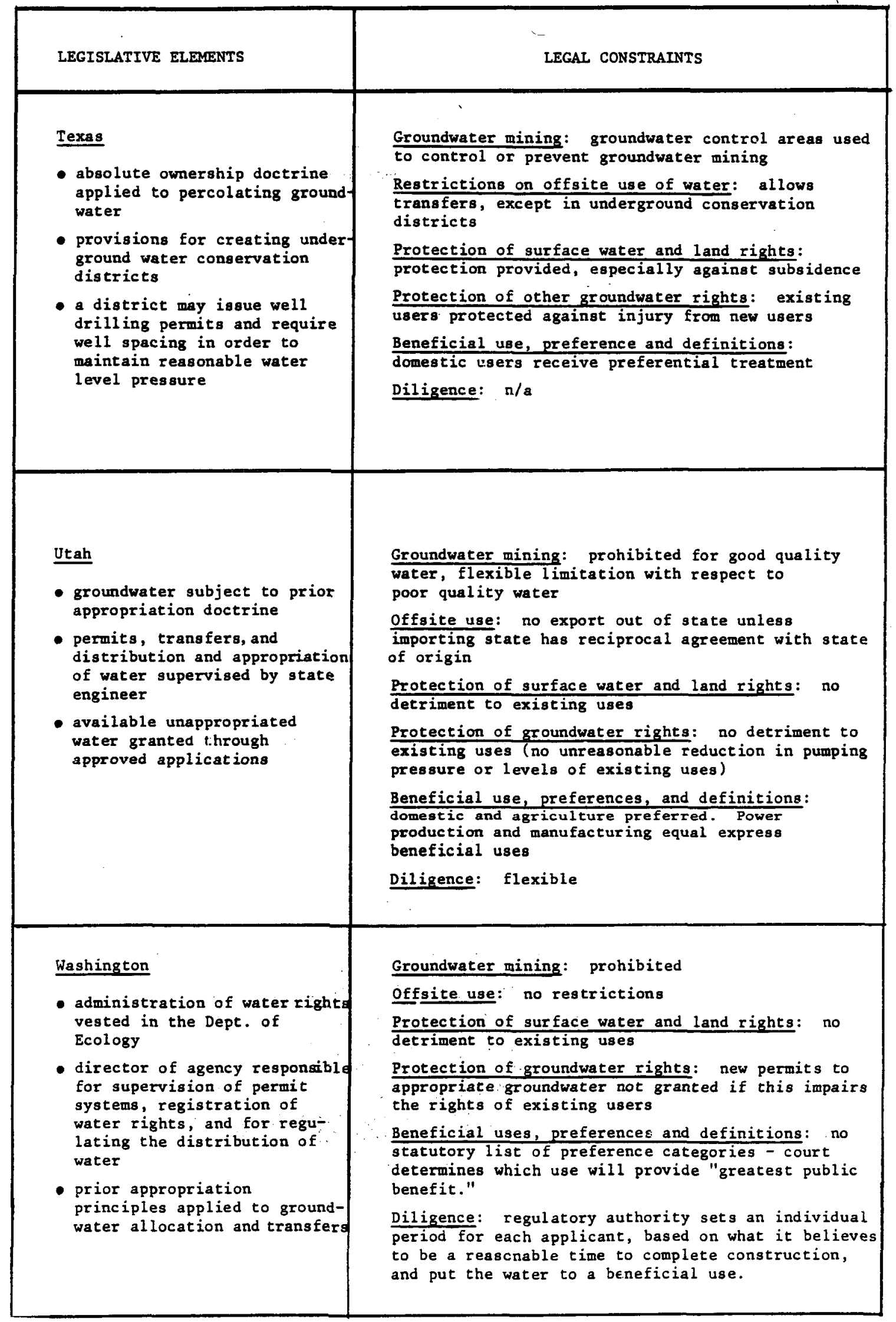


MAJOR LEGISLATIVE ELEMENTS AND THEIR CONSTRAINTS ON

GEOTHERMAL ENERGY DEVELOPMENT IN THE WESTERN STATES

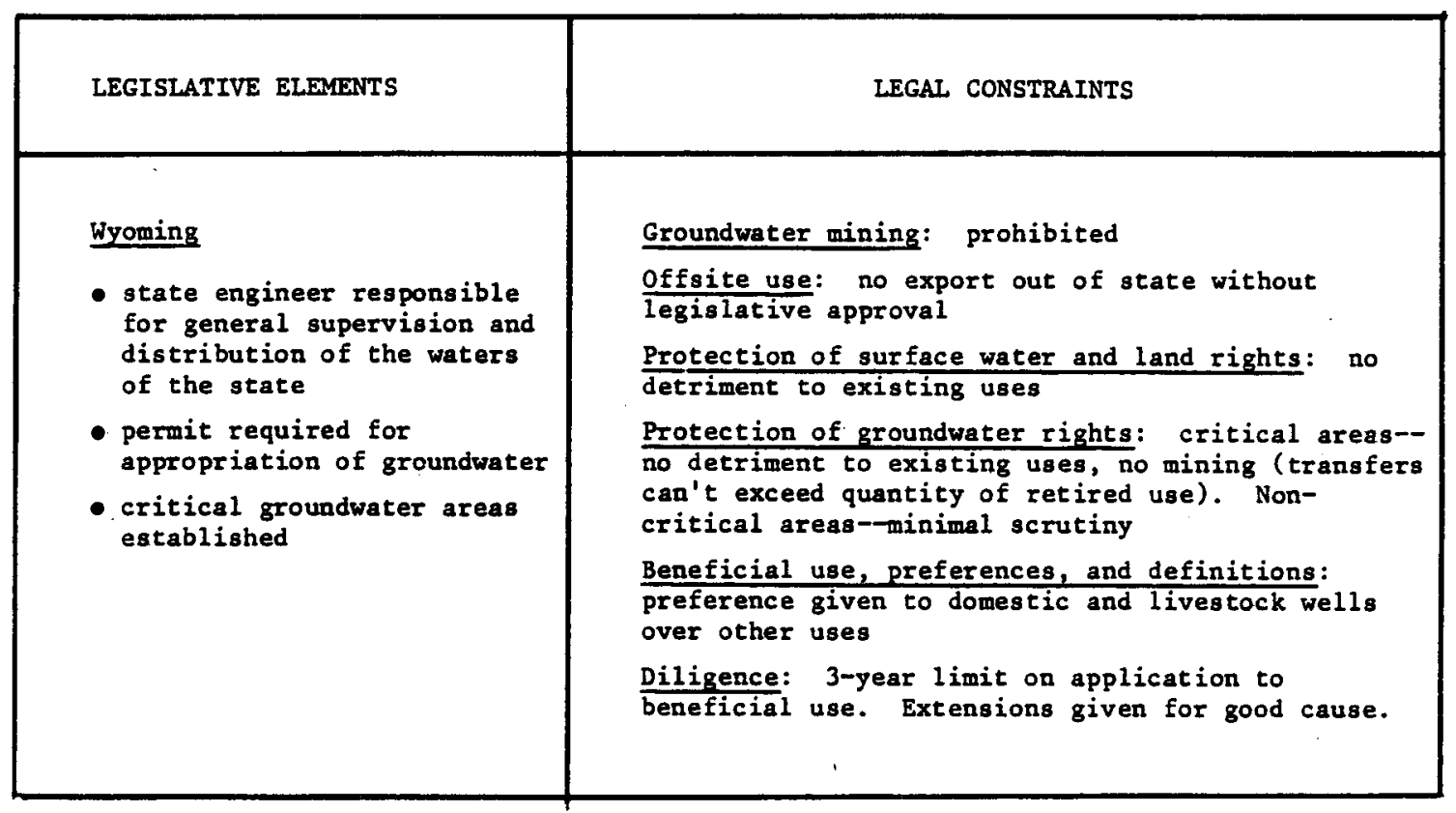


- Beneficial Use, Preferences, and Definition. Generally, primary preference is given to domestic use, and selective preference for agricultural use. Industrial use, particularly energy use, has lowest priority.

- Diligence Requirements. Many states require that the water acquired be used diligently after water rights are granted. Many states also prohibit the speculative private marketing of water rights. 
5.11 What are the roles of the various levels of government and their efforts in addressing the many problems associated with water availability?

There are many Federal agencies dealing with the management of water resources. Exhibit 5.18 lists the Federal agencles that have major responsibilities regarding water resources issues. The functions performed by each Federal agency with budget responsibility for water planning, management, and operations are briefly described below:

- Department of Interior has the lead responsibility in water resources research and data collection including desalination, conservation, administration of certain scenic rivers, weather modifications and development and operation of irrigation and multi-purpose water resource projects. The functions are carried out mainly by the office of Water Research and Technology (OWRT).

- The Office of Water Research and Technology (OWRT) was established by Secretarial Order in 1974, consolidating the functions of the former Office of Saline Waters and the Water Resources Research. OWRT's effort has been focusing on water resources research with programs directing towards identifying existing and anticipated future water problems. It supports 54 individual water resource research institutes, located at each State Land Grant University and in the District of Columbia, Guam, Virgin Island and Puerto Rico. These institutes conduct and encourage basic and applied research, develop statewide programs for resolving water problems, and disseminate research results for practical application.

- U.S. Geological Survey (USGS) maintains networks of staging stations on major waterways and acquires steam flow data, as well as water quality data for surface and groundwater.

- Burea of Reclamation assists state and local governments, and other federal agencies to stabilize and stimulate local and regional economics through development of water and related land resources in the 17 contiguous western states. Its water-related activities include municipal and industrial water supply, hydroelectric power generation, irrigations, water quality improvement, fish and wildlife enhancement, river regulation and control and other related use.

- Water Resources Council (WRC) was established by the Water Resources Planning Act of 1965 (P.L. 89-80) to implement a policy of water conservation. It continuously monitors the 


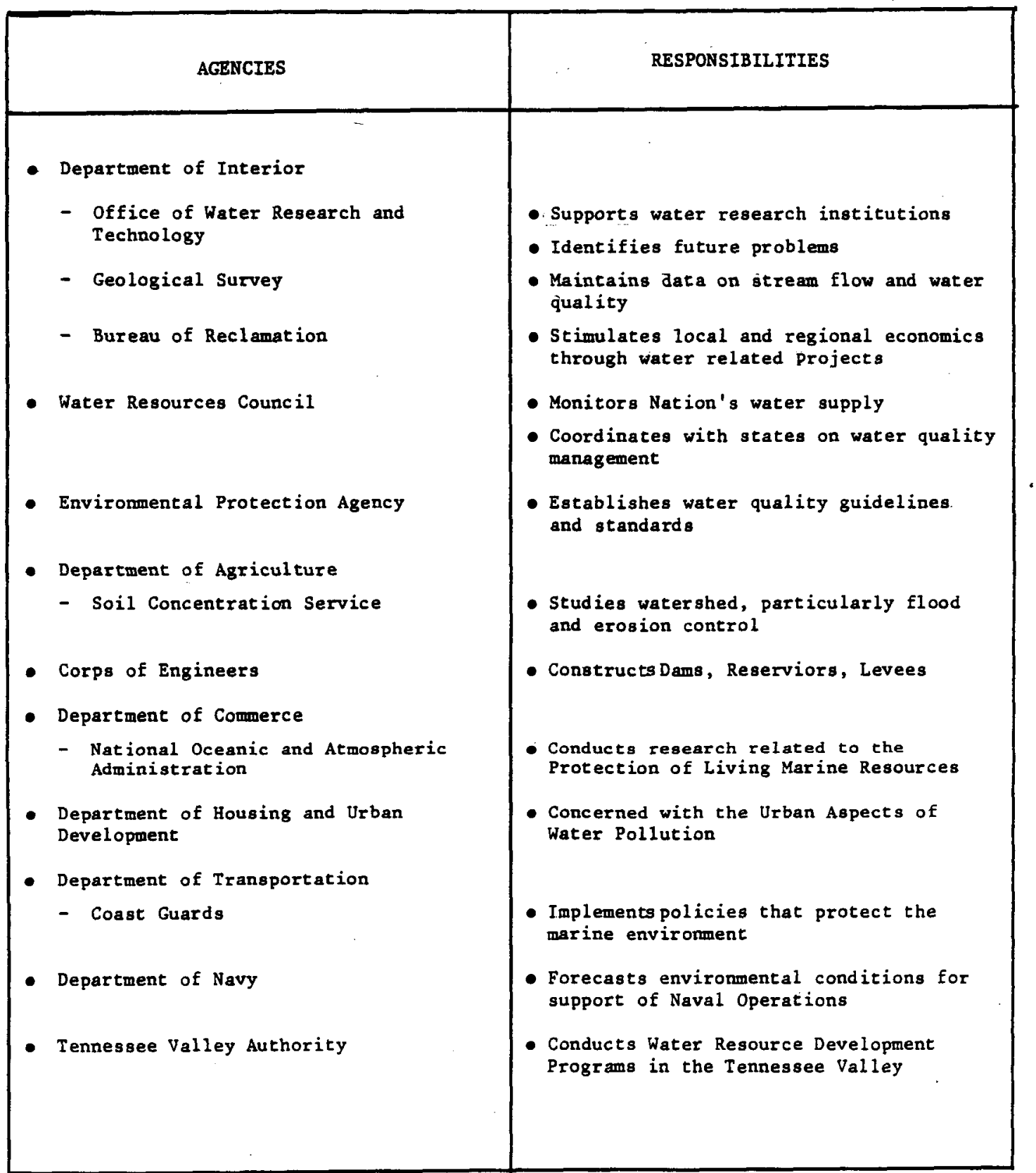


nation's water supply and needs and periodically reports its fidings in a national assessment of water resources. Working with river basic commissions, interagency commission and the states, WRC helps to finance and foster state-Federal cooperation and coordination in many aspects of water resource management.

- Environmental Protection Agency's (EPA) water quality activities represent a coordinated effort to restore the integrity of the nation's water. It coordinates and support research activities by state and local government, private and public groups and educational institutions. It also develops regulations for water pollution control and water supply; water quality standards; and effluent limitation guidelines.

- Department of Agriculture's (USDA) involvement in water related activities is primarily through the Soil Conservation Service (SCS). The SCS corporates with other Federal, state, and local agencies in studying the watershed of rivers and other waterways, including the development of water resource program, flood plain management, erosion control, farm irrigation, water-based recreation, fish and wildlife facilities, agriculture-related pollution control and water quality.

- Corps of Engineers under the direction and supervision of the Secretary of the Army is the Nation's major Federal water resources development activity and involves engineering works such as major dams, reservoirs, levees, harbors, waterways, locks and other types of structures. These activities provide flood protection, reduce cost for transportation, supply water for municipal and industrial use, generate hydroelectric power, regulates the rivers for many purposes including improvement of water quality, enhancement of fish and wildife, and the protection of shorelines.

- National Oceanic and Atmosphere Administration (NOAA), U.S. Department of Commerce conducts an integrated program of management, research, and services related to the protection and rational use of living marine resources. It is also active in conducting research and services relating to the oceans and inland waters. NOAA acquires, strives, and disseminates worldwide environmental data through a system of meterological, oceanographic, geodetic and seimological data centers.

- Department of Housing and Urban Development (HUD) is concerned primarily with the municipal and urban aspects of water and related land resources, including flood insurance and urban hydrology. Emphasis is placed on environmental and land use planning, and environmental management practices. 
- U.S. Coast Guard of the Department of Transportation has major responsibilities in implementing the nation's policies for the protection of the marine environment, and to minimize the damage caused by pollution discharges.

- Department of Navy provides forecasting of environmental conditions in the atmosphere, at the air-sea interface, and in the ocean primarily for support of naval operation.

- Tennessee Valley Authority (TVA) is a corporation of the Federal government that conducts a unified program of resource development for the advancement of economic growth in the Tennessee Valley region. The authority's program of activities includes flood control, navigation development, electric power production, fertilizer development, recreation improvement and forestry and wildlife development.

In addition, there are bilateral organizations that are actively involved in the preservation and use of boundary waters. The International Boundary and Water Commission (comprised of United States and Mexico), is responsible for implementing the provisions of existing treaties dealing with boundary and water matters, including control of floods on the boundary rivers, improvement of water quality and use of the boundary section of the Rio Grande to jointly develop hydroelectric power. Similarly, the International Joint Commission (IJC), United States and Canada was established to prevent dispute regarding the use of boundary waters (the Great Lakes), and settle questions regarding rights, obligations, or interest of U.S. and Canada along the common frontier.

At the state level, research and development efforts are relatively small compared to the Federal level. However, states are responsible for enforcing the regulations and standards promulgated under the Clean Water Act and the Safe Drinking Water Act. There are also river basin commissions established at numerous river basins to serve as the principal coordinating agencies for water and waterrelated land management plans. In addition, most states have their 
own Department of Resources or equivalent to handle water allocation, water use, and permit administration.

Most water problems related to supply and demand occur at the local levels. County and city governments can promote (or conversely discourage) suitable development of geothermal energy resources within their local domain through the administratio of water rights and use permits. Land use planning and zoning ordinances are also effective in fostering industrial growth, or to provide incentive to geothermal development. 
5.12 What types of R\&D and planning and management efforts are required to resolve the water availability problems?

There are three fundamental approaches that can be taken towards resolving the water availability problem associated with geothermal development, namely 1) reduction of water requirement; 2) increase or augmentation of water supplies, and 3) removal of institutional barriers associated with water use. The types of R\&D and planning and management activity alternatives needed to address the water availability problem are shown in Exhibit 5.19 .

Reduction of water requirements in geothermal power plants can be achieved through process modification. The technical feasibility of using dry towers or wet/dry towers has been discussed in Section 5.6. Other methods of reducing water consumption include:

- Improvement of Thermal Efficiency. Using higher quality materials in the heat exchange units and better design of same may lead to an improvement of the overall thermal efficiency. Consequently, less heat will be dissipated and the make-up water requirements will be reduced.

- Use of Better Quality Water for Cooling. This would allow the increase of the concentration factor in the cooling cycle, thereby reducing the amount of blowdown requirements.

- Water Reuse and Recycle. Water use in the air abatement system could be of marginal quality. Use of cooling tower blowdown water in the air abatement system will reduce the water consumption requirement.

A fundamental problem with geothermal energy development is that geothermal resources generally occur in areas where the physical availability of water is limited. However, water supply sources can be augmented through the following activities.

- Desalination. Converting salt water to fresh water is certainly a way to increase water supply. Desalination is generally done by distillation or by membrane processes, such as reverse osmosis. The state-of-the-art of desalination is adequate. The major barrier appears to be economics. 


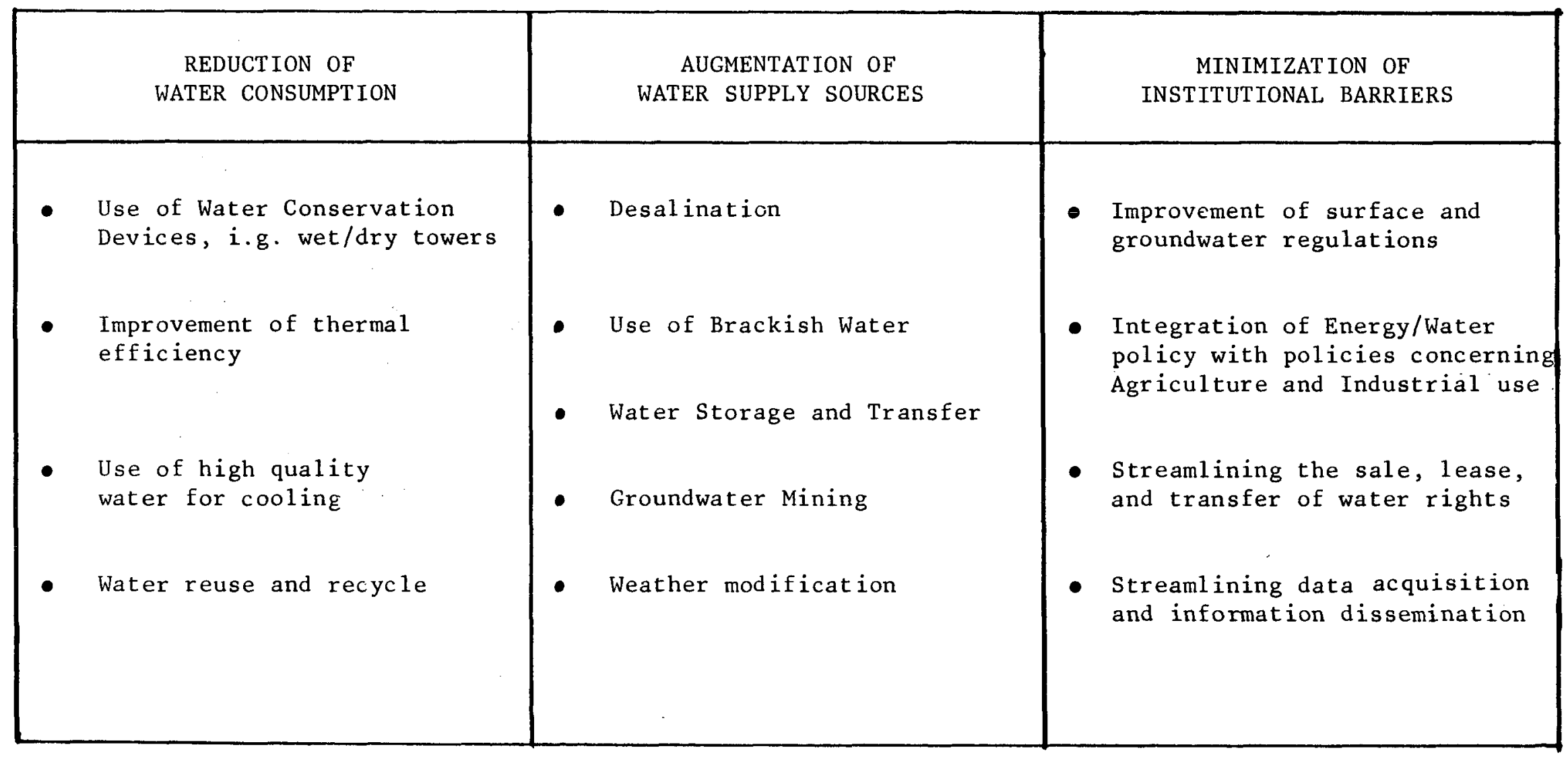

\section{EXHIBIT 5.19}

MAJOR R\&D AND PLANNING AND MANAGEMENT ACTIVITIES REQUIRED TO ADDRESS WATER AVAILABILITY PROBLEMS 
- Use of Brackish Waters. While some regions may not have adequate supply of fresh water, there may be adequate amounts of marginal quality water which could be used as make-up water to help satisfy the water demand.

- Water Storage and Transfer. Large scale water storage and transfer systems are made through the use of reservoirs, impoundments, aqueducts, tunnels and pipelines. In addition to cost, ecological and environmental effects of interbasin transfer need to be investigated in detail.

- Weather Modification. Artificially induced precipitation so as to increase runoff is the common method for "weather modification". However, the opportunity to use these techniques are highly site specific. Research on this process is proceeding, but at present, it must be considered as a potential source with limited application.

The legal/institutional systems in many of the states with potential geothermal resources have inadvertantly created barriers to geothermal development, many of which can only be resolved through lengthy (and costly) legal processes. The resolution of conflicting regulations and the integration of water use policies are important steps towards minimizing the institutional barriers. Specifically, there are needs to perform the following:

- Modification of Surface and Groundwater Regulations. Surface and groundwater regulations are often in conflict with each other. Since much of the nation's groundwater is physically connected to the surface flow, surface and groundwater sources in many areas can be more effectively managed together.

- Integration of Water Use Policies. Many states can purposely create barriers to the use of water for energy development by simply declaring such use as non-beneficial. There is therefore a need to integrate the various water use policies, particularly the ones related to energy, agriculture, and industry.

- Streamlining the Sale, Lease and Transfer of Water Rights. Generally, obtaining water rights is a lengthly process, particularly when its approval hinges upon other permit application systems. Steamlining of the application process will facilitate geothermal development. 
- Streamlining Data Acquisition and Information Dissemination. Water quality and water supply data, particularly groundwater data, is generally lacking. Better methods are needed for integrating, sharing, synthesizing, analyzing, and displaying groundwater information. In addition existing data bases need to be coordinated and strengthened. 
5.13 How is the Division of Geothermal and Hydropower Technology addressing the water avallability problems?

The availability of water for geothermal energy development is very site specific. It depends upon its physical availability, existing use and allocation, the local political and environmental factors, as well as the local citizens' attitude toward diverting water for geothermal use. Generic studies on water availability cannot be used as substitute for site specific studies.

DOE/GHTD, through the Oak Ridge National Laboratory, has funded a study in water-related constraints to geothermal development.7 In addition, a review of water resource potential for developing geothermal resource site has been funded through DOE. 5

Of the many environmental issues addressed by GHTD, injection monitoring is among the top priorities to be investigated. Topics being Investigated or to be addressed in this area include:

- State-of-the-art approaches to monitoring the movements. of injected fluids.

- Impact of ground water regulations on geothermal injection operations.

- Use of subsurface pressure monitoring for understanding and predicting (modeling) fluid movements.

- Methods for measuring fluid dispersion coefficients in typical injection rock formations and use of these coefficients in numerical modeling.

- Applications of injection wells and special monitor wells to injection monitoring, including innovative techniques.

- Case studies of long-term non-geothermal injection experience (e.g., for oilfield brines, wastewater, underground water storage). 
Many of these activities are related to water use and applications but solution of water availability problems will involve extensive coordination and cooperation among many levels of governments, as well as the geothermal developers and the private citizen. The Interagency Geothermal Coordinating Council (IGCC)12 appears to be the most appropriate governing body to coordinate these various activites. 


\section{REFERENCES}

1. Engineering and Economics Research, Inc., Potential Hydrological Effects of Geothermal Fluid Withdrawal and Injection. EER TR-14-81, U.S. Department of Energy, Geothermal and Hydropower Technology Division, Washington, D.C. 1981

2. U.S. Water Resources Council, The Nation's Water Resources 19752000, Washington, D.C. 1975

3. Robertson, R.C., "Waste Heat Rejection from Geothermal Power Station", in J. Kestin, ed. Sourcebook on the Introduction of Electricity from Geothermal Energy. U.S. Department of Energy, DOE/RA/28320-2, Washington, D.C. 1980

4. U.S. Department of Energy, Technology Characterizations Environmental Information Handbook, DOE/EV-0072, Washington, D.C. 1980

5. Hanford Engineering Development Laboratory, A Review of Water Resource Potential for Developing Geothermal Resource Sites in the Western United States. HEDL-TME 79-74 UC-66C, Richland, Washington 1980

6. The John Muir Institute, Inc., Institutional Constraints on Alternative Water for Energy - A Guidebook for Regional Assessment, U.S. Department of Energy, DOE/EV/10/80-1, Washington, D.C. 1980

7. Robertson, R.C., Water-Related Constraints to the Development of Geothermal Electric Generating Stations, Oak Ridge National Laboratory, ORNL/TM-7718, Oak Ridge, Tennessee 1981

8. Horsak, R.D., R.W. Beck and Associates. Heat Rejection from Geothermal Power Plants Prepared for California Energy Commission and Electric Power Research Institute, Palo Alto, California, EPRI ER-1216, 1976

9. Strauss, S.D., District Heating Links with Cogeneration Power, $123(8) 72-75,1979$

10. Beeland, G.V., Survey of Environmental Regulations Applying to Geothermal Exploration, Development and Use, WAPORA, Inc., Washington, D.C. 1981

11. Olpin, 0. et al, Geothermal Development and Western Water Law, Utah Law Review, 1979: 773-887

12. Kenkeremath, D.C. and C.A. McDonald, Interagency Environmental Controls Research Strategy for Geothermal Energy Development, Engineering and Economics Research, Inc., TR-04-81, Apr 1981 
APPENDIX A

WATER RESOURCES CHARACTERISTICS AT

34 MAJOR KGRAs 
This appendix contains site specific information on thirty-four (34) Known Geothermal Resource Areas (KGRA) in the Western States. It highlights geothermal resource potential, water resource limitation and existing water use in the area. 
Geothermal Resource Characteristics:

- 150 MWe of generating capacity to be installed prior to 1990 ;

- Well temperature $325^{\circ} \mathrm{F}$ to $363^{\circ} \mathrm{F}$;

- Binary cycle with complete recharge to prevent subsidence;

o Water requirement 3,500 to $4,500 \mathrm{gal} / \mathrm{min} / 100 \mathrm{MWe}$.

Water Resource Limitations:

- Availability of water in central Arizona is limited;

- Geothermal development require dual purpose; electric energy and desalination.

Surface Water:

- Salt River - North of Chandler KGRA

- Stream flow intermittent;

- Gila River - Water supply has been fully utilized

- Stream flow - irregular.

\section{Groundwater:}

- Overdraft rate at 3 million - acre - ft.

Competing Water Demands:

o Total consumptive demand - 6,500 Mgd;

- Critical consumptive demand occurs in July 3,273 Mgd;

- Major use is for agriculture.

\section{Conclusion:}

- Water availability will be a significant problem from Chandler KGRA. 
Geyser Bight KGRA, Alaska

\section{Geothermal Resource Characteristics:}

- Estimated potential 136 MWe for $30 \mathrm{yrs;}$

- Median temp. of reservoir $406^{\circ} \mathrm{F}$.

Water Resource Limitations:

- Frozen streams and lakes.

Surface Water:

- Abundant ocean water;

- Streams and lakes frozen for long periods - not a practical source of water.

Groundwater:

Competing Water Demands:

Conclusion:

- Water avallability should not be a problem in the development of geothermal energy. 


\section{Geothermal Resource Characteristics:}

- 50 MWe of generating capacity to be installed prior to 1990;

o Well temperature $212^{\circ} \mathrm{F}$ to $392^{\circ} \mathrm{F}$;

- Water requirement $2,500 \mathrm{gal} / \mathrm{minute} / 50 \mathrm{MWe}$.

\section{Water Resource Limitations:}

- Salt River - KGRA allocated near headwaters;

- Surface water entirely accounted for, based on demonstrated demand.

\section{Groundwater:}

- Availability unknown.

Competing Water Demands:

- Critical surface supply (CSS) is $287 \mathrm{Mgd}$;

- 1975 consumptive demand is $160 \mathrm{Mgd}$.

\section{Conclusion:}

- Water both surface and ground availability for developing the KGRA is unknown and expected to be extremely limited. 
Brawley KGRA, Imperial Valley, S. California

Geothermal Resource Characteristics:

- Proposed capacity to be installed prior to 2020 is 1000 MWe;

o Subsurface fluid temps $-446^{\circ} \mathrm{F}$ to $536^{\circ} \mathrm{F}$;

- Binary cycle used for developing resource;

o Water requirements - 3000 to $4000 \mathrm{gal} / \mathrm{min} / 100 \mathrm{MWe}$.

\section{Water Resource Limitations:}

- Located in Colorado Desert Subregion - largest diversion of Colorado water for irrigation, domestic and industrial use controlled by Imperial Irrigation District.

\section{Surface Water:}

- Colorado River - regulated flow; diversion and appropriation of river water; primary use in agriculture;

- New River - near annual discharge $600 \mathrm{ft}^{3}$ per second - nearly all water derived from irrigational runoff;

- Alamo River - formed from irrigational runoff; near annual discharge $950 \mathrm{ft}^{3}$ per second;

- Salton Sea - highly saline; water mainly derived from aggricultural runoff.

\section{Groundwater:}

- Safe groundwater yeild estimated to be 100,000 acre-ft per year; occurs in alluminum filled valleys;

- Imperial Valley groundwater is suitable for supplying cooling water, but generally not available at geothermal resource areas.

\section{Competing Water Demands:}

- Total consumptive demand estimated to be $3990 \mathrm{Mgd}$;

- Critical consumptive demand occurs in Oct - $2961 \mathrm{Mgd}$;

- Primary use of water is irrigation.

Conclusion:

- Availability of water for developing geothermal resources is limited, due to great demands in existing water resources. 
East Mesa KGRA, Imperial Valley, South California

Geothermal Resource Characteristics:

- Temperature of the resource is estimated at $358^{\circ} \mathrm{F}$;

- Secondary or binary process used for development;

- Water requirements estimated at 4000 to $5000 \mathrm{gal} / \mathrm{min} / 100 \mathrm{MWe}$.

Water Resources Limitation:

- Located in Colorado Desert Subregion - largest diversion of Colorado water for irrigation, domestic and industrial use controlled by Imperial Irrigation District.

Surface Water Sources:

- Colorado River - regulated flow; diversion and appropriation of river water; primary use is agriculture;

- New River - near annual discharge $600 \mathrm{ft}^{3}$ per second - nearly al1 water derived from irrigational runoff;

- Alamo River - formed from irrigational runnoff; near annual discharge $950 \mathrm{ft}^{3}$ per second;

- Salton Sea - highly saline; water mainly derived from agricultural runoff.

\section{Groundwater Sources:}

- Safe ground water yield estimated to be 100,000 acre-ft per year; occurs in alluminum fill valleys;

- Imperial Valley ground water most suitable for supplying cooling water, but generally not available at geothermal resource areas.

Competing Water Demands:

- Total consumptive demand estimated to be $3990 \mathrm{Mgd}$;

- Critical consumptive demand occurs in Oct. - $2961 \mathrm{Mgd}$;

- Primary use of water is irrigation.

\section{Conclusion:}

- Availability of water for developing geothermal resources is limited, due to great demands on existing water resources. 
Heber KGRA, Imperial Valley, South California

Geothermal Resource Characteristics:

- Sub-surface temperature ranges $320^{\circ} \mathrm{F}$ to $365^{\circ} \mathrm{F}$;

- Site selected for study of the feasibility of low salinity hydrothermal conversion;

- Candidate site for geothermal demonstration plant;

- Proposed capacity to be installed prior to 2020 - 1000 MWe.

\section{Water Resources Limitation:}

- Located in Colorado Desert Subregion - largest diversion of Colorado water for irrigation, domestic and industrial use controlled by Imperial Irrigation District.

\section{Surface Water Sources:}

- Colorado River - regulated flow; diversion and appropriation of river water; primary use is agriculture;

- New River - near annual discharge $600 \mathrm{ft}^{3}$ per second - nearly all water derived from irrigational runoff;

- Alamo River - formed from irrigational runnoff; near annual discharge $950 \mathrm{ft}^{3}$ per second;

- Salton Sea - highly saline; water mainly derived from agricultural runoff.

Groundwater Sources:

- Safe ground water yield estimated to be 100,000 acre-ft per year; occurs in alluminum fill valleys;

- Imperial Valley ground water most suitable for supplying cooling water, but generally not available at geothermal resource areas.

\section{Competing Water Demands:}

- Total consumptive demand estimated to be $3990 \mathrm{Mgd}$;

- Critical consumptive demand occurs in 0ct. - $2961 \mathrm{Mgd}$;

- Primary use of water is irrigation.

\section{Conclusion:}

- Availability of water for developing geothermal resources is limited, due to great demands on existing water resources. 
Salton Sea KGRA, Imperial Valley, South California

Geothermal Resource Characteristics:

- Total installed electrical energy potential approx. 2000 MWe;

- Secondary working fluid on binary process used for development;

- Temperature of the hypersaline brine $680^{\circ} \mathrm{F}$;

- Water requirement approx. $2500 \mathrm{gal} / \mathrm{min} / 100 \mathrm{MWe}$.

Water Resources Limitation:

- Located in Colorado Desert Subregion - largest diversion of Colorado water for irrigation, domestic and industrial use controlled by Imperial Irrigation District.

Surface Water Sources:

- Colorado River - regulated flow; diversion and appropriation of river water; primary use is agriculture;

- New River - near annual discharge $600 \mathrm{ft}^{3}$ per second - nearly all water derived from irrigational runoff;

- Alamo River - formed from irrigational runnoff; near annual discharge $950 \mathrm{ft}^{3}$ per second;

- Salton Sea - highly saline; water mainly derived from agricultural runoff.

Groundwater Sources:

- Safe ground water yield estimated to be 100,000 acre-ft per year; occurs in alluminum fill valleys;

- Imperial Valley ground water most suitable for supplying cooling water, but generally not avallable at geothermal resource areas.

Competing Water Demands:

- Total consumptive demand estimated to be $3990 \mathrm{Mgd}$;

- Critical consumptive demand occurs in Oct. - 2961 Mgd;

o Primary use of water is irrigation.

Conclusion:

o Availability of water for developing geothermal resources is limited, due to great demands on existing water resources. 
Westmorland KGRA, Imperial Valley, Southern California

\section{Geothermal Resource Characteristics:}

- Estimated resource potential over a 30 year period - 1710 MWe;

- Mean resource temperature $423^{\circ} \mathrm{F}$.

\section{Water Resource Limitations:}

- Availability of water limited;

- High salinity of available water.

- Too costly to pump water from great distances;

\section{Surface Water:}

o Water from New River possible source for development.

Groundwater:

- Safe ground water yield estimated to be 100,000 acre-ft per year; occurs in alluvium filled valleys;

- Imperial Valley ground water most suitable for supplying cooling water; but generally not available at geothermal resource areas.

\section{Competing Water Demands:}

- Total consumptive demand estimated to be $3990 \mathrm{Mgd}$;

- Critical consumptive demand occurs in 0ct. - $2961 \mathrm{Mgd}$;

o Primary use of water is irrigation.

\section{Conclusion:}

- Availability of water would be a significant problem. 
Clear Lake Volcano KGRA, California

Geothermal Resource Characteristics:

- Estimated potential - 900 MWe for 30 years;

- Median temperature of reservoir $-374^{\circ} \mathrm{F}$;

- No commercial development at Clear Lake.

Water Resource Limitations:

- Aesthetic and recreational values limit availability of water.

Surface Water:

- Clear Lake - withdrawal of water would be a problem.

Groundwater:

- Available ground water not sufficient for geothermal power facility.

Competing Water Demands:

o Major use is for recreational purposes.

Conclusion:

- Availability of water would be a considerable problem in the development of geothermal resources. 


\section{Geotherma1 Resource Characteristics:}

- Field limits currently estimated to be $2500 \mathrm{MWe}$

- Vapor-dominated convective resource;

- Condensation of steam results in surplus of water;

- Undeveloped liquid dominated convective resource located around periphery of KGRA;

- Temp. range of $446^{\circ} \mathrm{F}$ to $482^{\circ} \mathrm{F}$;

- Water requirement estimated at $4000 \mathrm{gal} / \mathrm{min} / 100 \mathrm{MWe}$.

\section{Water Resource Limitations:}

o No water shortages anticipated in developing The Geysers.

- Some cooling water required for liquid - dominated resource.

\section{Surface Water:}

- Russian River - flows along west side of KGRA

- draws area of approx. $800 \mathrm{sq}$. miles above the lower boundary of KGRA;

- no major diversions.

- Cache Creek - East of KGRA

- completely regulated flow;

- heavy irrigation demands.

- Clear Lake - Natural lake; regulated at outlet end, storage capacity exceeds $1 \times 106 \mathrm{AC}-\mathrm{ft}$.

\section{Groundwater:}

- Undeveloped resources of ground water in alluvium-filled valleys;

- Obtainable yield $500 \mathrm{gal} / \mathrm{min}$.

\section{Competing Water Demands:}

- Total consumptive demand - $933 \mathrm{Mgd}$;

- Critical consumptive demand occurs in September;

- Primary use is irrigation.

\section{Conclusion:}

- Water availability will not be a significant problem in the development of The Geysers for geothermal purposes. 


\section{Glass Mountain KGRA, California}

Geothermal Resource Characteristics:

- Liquid dominated resource;

- 50 MWe of generating capability to be installed over a 30 year period;

- Geothermal resource temperature estimated to exceed $392^{\circ} \mathrm{F}$;

o Either flash steam process or binary cycle could be used for development;

- Water requirement estimated to range from 4000 to 500 $\mathrm{gal} / \mathrm{min} / 100 \mathrm{MWe}$.

\section{Water Resource Limitations:}

- Most of the Glass Mt. KGRA located at altitude above $6000 \mathrm{ft}$; surface drainage poorly developed;

- No perennial streams.

\section{Surface Water:}

- Medicine Lake - occupies a volcanic crater within a small closed drainage basin;

- Clear Lake Reservoir - water designated for wildlife refuge.

\section{Groundwater:}

- Four ground water basins located in the vicinity of the Glass Mt. KGRA.

\section{Competing Water Demands:}

- Total consumptive demand estimated to be $1481 \mathrm{Mgd}$;

- Critical consumptive demand estimated to be $3087 \mathrm{Mgd}$, occurs during October.

\section{Conclusion:}

- Both surface and ground water resources are limited, therefore, water availability may be a considerable problem. 
Geothermal Resource Characteristics:

- Plan calls for a total development of 2000 MWe;

- Liquid dominated resource;

- Sub-surface temp. in excess of $302^{\circ} \mathrm{F}$;

- Evidence of subsidence - $100 \%$ recharge required for development;

- Binary-type system required for development;

o Water requirements estimated to be $5000 \mathrm{gal} / \mathrm{min} / 100 \mathrm{MWe}$.

\section{Water Resource Limitations:}

- Most water used for agriculture, lumbering, mining and recreation;

- Unregulated stream flow;

- Water shortage during irrigational season.

\section{Surface Water:}

- Major surface water resources located West of Warner Mountain;

- Bidwell Creek - unregulated flow;

- about $2 \mathrm{ft}^{3}$ per second diverted for irrigational usage;

- South Fork Pit River - partially regulated

- significant diversion of water for irrigation;

o North Fork Pit River - partially regulated flow/diversion for irrigation;

- Goose Lake - would require major diversion effort for cooling purposes.

\section{Groundwater:}

- Considerable amounts of usable ground water occurs in the valleys;

- Total storage capacity within $400 \mathrm{ft}$ of ground surface estimated to be 4,000,000 acre-ft.

- Total consumptive demand - 7,132 Mgd;

- Critical consumptive demand occurs in September - $9407 \mathrm{Mgd}$;

- Major use is irrigation.

Conclusion:

- Limited surface and ground water supplies would pose considerable problems for geothermal development. 
Geothermal Resource Characteristics:

- Vapor and liquid-dominated resource;

- Sub-surface temperatures of resource estimated to be approx. $464^{\circ} \mathrm{F}$;

- Flash-steam process or binary type system used for development;

- Water requirements estimated to range from 0 to 4000 $\mathrm{gal} / \mathrm{min} / 100 \mathrm{MWe}$.

Water Resource Limitations:

- Abundant water resources;

- Small lakes are common features.

\section{Surface Water:}

o North Fork Feather River - runoff estimated at approx. 17 in/yr - no upstream regulation and diversion;

- Butte Creek - average annual discharge $85 \mathrm{ft}^{3}$ per second - no diversion or regulation;

- Lake Almanon - serves multiple purposes; major use is hydroelectric power generation.

\section{Groundwater:}

- Groundwater exists in Lake Almanon Valley

Competing Water Demands:

- Total consumptive demand - 7,132 Mgd;

- Critical consumptive demand occurs in September - 9,707 Mgd.

Conclusion:

- Water availability is no problem, but development of KGRA would require approval by the U.S. Forest Service. 
Coso KGRA, South Central California

\section{Geothermal Resource Characteristics:}

- Mean research temperature is estimated to be $446^{\circ} \mathrm{F}$;

- Flash steam expansions process used for developing resource;

- Water requirement estimated to be between 0 to 4,500 $\mathrm{ga} 1 / \mathrm{min} / 100 \mathrm{MWe}$;

- 600 MWe capacity estimated to be developed prior to 1990.

Water Resource Limitations:

- Outside sources of makeup water reuqired for power plant operation.

Surface Water:

o Little rainfall;

- Los Angeles Aqueduct and Reservoir, the only significant surface-water resources, are owned and controlled by Los Angeles Department of Water and Power.

Groundwater:

- Seepage from Haiwce Reservoir only major source of groundwater;

- Recharge from Halwce Reservoir estimated to be 11,000 acre-ft per year;

- Pumpage rates exceeds 15,000 acre-ft per year.

Competing Water Demands:

- Total consumptive demand $377.6 \mathrm{Mgd}$;

- Critical consumptive demand occurs in Oct.;

- Competition for water from community of China Lake and the Naval Weapons Station.

Conclusion:

- Availability of water for geothermal development will be a significant problem due to competition for already insufficient water supplies. 
Geothermal Resource Characteristics:

- High enthalpy liquid dominated resource;

- Subsurface temps. in excess of $428^{\circ} \mathrm{F}$;

- Both flash-steam and binary fluid processes suitable for development;

- Low level of seismic activity - sink holes indicate subsidence;

- Water require. are estimated to be 0 to $4000 \mathrm{ga} 1 / \mathrm{min} / 100 \mathrm{MWe}$.

Water Resource Limitations:

- Agriculture and industry place great demands on available water resources;

- Use of groundwater exceeds the annual recharge.

\section{Surface Water Resources:}

- Surface water resources have been extensively developed;

- Mean annual national runoff - $1.2 \times 106$ acre-ft;

- Export to other subregion exceeds 350,000 acre-ft;

- Owen River - estimated drainage basin area above Lake Crowley is 4,000 sq. miles; mean annual discharge approx. $150 \mathrm{ft}^{3}$ per second; considerable demand on its water;

- Lake Crowley - Owens River flows both in and out of Lake Crowley; resource managed by City of Los Angeles Department of Water and Power;

- Mono Lake - closed drainage basin; part of the surface water development in the South Lahoutan subregion operated by the City of Los Angeles.

Groundwater:

- Most usable groundwater located in scattered alluvium-filled valleys; consolidated rock formation contain only small quantities of recoverable groundwater;

- About 50 valley-filled aquifers may be significant resources of groundwater.

\section{Competing Water Demands:}

- Demand for water is great;

- Total consumptive demand is $377.6 \mathrm{Mgd}$;

- Critical consumptive demand occurs in October;

- Average export of water $350 \mathrm{Mgd}$;

- Consumptive demand from irrigational usage ranges as high as $700 \mathrm{mgd}$ during summer.

\section{Conclusion:}

The currently high demand on existing water supplies makes water availability a critical problem for geothermal development. 
Kamali Homesteads (Puna District) KGRA, Hawaii

Geothermal Resource Characteristics:

- Estimated potential 210 MWe for 30 years;

- Median temp. $523^{\circ} \mathrm{F}$.

\section{Water Resource Limitations:}

- Salt water encroachment could be a problem due to large scale pumping of ground water.

\section{Surface Water:}

o No surface water due to high permeability of soil and bedrock.

Groundwater:

- Large volumes of ground water - high rainfall - permeable soil.

Competing Water Demands:

o It is not likely that water supply will constrain development in the Puna District. 


\section{Geothermal Resource Characteristics:}

- Resource potential 800 MWe;

- Temperature $284^{\circ} \mathrm{F}$;

- Binary cycle process used for development;

- Water requirement 350 to $400 \mathrm{gal} / \mathrm{min} / 5 \mathrm{MWe}$.

\section{Water Resource Limitations:}

- Availability of water limited.

\section{Surface Water:}

- Raft River only surface water resource in vicinity of KGRA.

\section{Groundwater:}

- Existing ground water not available for cooling the 5 MWe demonstration plant;

- Sometimes large quantities of groundwater available from limestone deposits.

\section{Competing Water Demands:}

- Water used for irrigation purposes.

\section{Conclusion:}

- All surface and near surface water of the Raft River basin has been allocated, therefore, water availability will be a significant problem. 


\section{Bruno-Grandview KGRA, Idaho}

\section{Geothermal Resource Characteristics:}

- Resource potential estimated to be 3000 MWe;

- 150 MWe of generating capacity to be installed prior to 1990;

- Average reservoir temperature $230^{\circ} \mathrm{F}$;

- Binary cycle used for developing resource;

o Water requirement range as high as $4500 \mathrm{gal} / \mathrm{min} / 100 \mathrm{MWe}$.

\section{Water Resource Limitations:}

- Availability of water limited;

- Snake River entrenched in deep canyon;

o Large amounts of water used for irrigation, which extends to Oregon and Nevada.

Surface Water:

- Snake River major surface water resource.

\section{Groundwater:}

- Permeable sand and gravel deposits yield moderate to large amounts of ground water.

\section{Competing Water Demands:}

o Large amounts of water diverted for irrigation;

- Water rights doctrine of appropriation based upon beneficial usage is used for allocating water.

Conclusion:

- Water supply already limited; continued expansion of high lift pumping stations will further reduce supplies, therefore, water availability could be a major problem. 


\section{Weiver - Crane Creek KGRA, Idaho}

\section{Geothermal Resource Characteristics:}

- Resource potential 1000 MWe;

- Estimated subsurface temperature approx. $284^{\circ} \mathrm{F}$;

- Binary fluid conversion process required to develop resource;

- Water requirement estimated to be as high as 67000 $\mathrm{gal} / \mathrm{min} / 100 \mathrm{MWe}$.

\section{Water Resource Limitations:}

- Both ground and surface water available.

\section{Surface Water:}

- Weiser River, Weiser, Idaho - average annual flow rate is 1176 ft $3 / 5$ - partially regulated by Crane Creek Reservoir upstream diversions for irrigation are samll.

- Snake River - located within 30 miles of KGRA - average annual flow rate at Weiser is approx. $18,000 \mathrm{ft}^{3}$ per second.

Groundwater:

- Both Snake and Weiser River basins have permeable sand and gravel deposts from which moderate to large quantities of ground water can be pumped.

\section{Competing Water Demands:}

\section{Conclusion:}

- Offers good potential for geothermal development, with regard to availability of both surface and ground water. Also, there is very little diversion for irrigation and other purposes. 
Geothermal Resource Characteristics:

Stillwater Area

- Estimated potential 450 MWe for 30 years;

- Average temperature $318^{\circ} \mathrm{F}$.

\section{Soda Lake}

- Estimated potential 146 MWe for 30 years;

- Mean temperature $315^{\circ} \mathrm{F}$.

Water Resource Limitations:

- Lakes and reservoirs part of Stillwater National Wildlife Refuge;

o Water not available for diversion.

\section{Surface Water Resources:}

- Numerous lakes and reservoirs - but water not available;

- Irrigation canals - water availability uncertain.

\section{Groundwater:}

- Abundant ground water - inflow to Carson sink - accummulated agricultural effluents from irrigation;

- High salinity.

Competing Water Demands:

Conclusion:

- Water availability would be a significant problem. 
Desert Peak KGRA, Nevada

\section{Geothermal Resource Characteristics:}

- Estimated resource potential 750 MWe for 30 years;

o Average temperature of resource $430^{\circ} \mathrm{F}$.

\section{Water Resource Limitations:}

- Demand for water exceeds supply;

- Water totally appropriated for irrigation.

\section{Surface Water:}

o Humboldt River flowing into Humboldt Lake and Foulan Lake.

\section{Groundwater:}

- Groundwater is abundant, but of poor quality.

\section{Competing Water Demands:}

- Major use - irrigation;

o Current water use $-200,000$ acre-ft year.

\section{Conclusion:}

- May be possible to buy water, but demand exceeds supply so water availability would be a significant problem. 


\section{Geothermal Resource Characteristics:}

- 100 MWe of capacity to be developed prior to 1990;

- Temperature of resource is set at $410^{\circ} \mathrm{F}$;

- Capacity 200 MWe;

- Water requirements estimated to range from 0 - 4500 $\mathrm{gal} / \mathrm{min} / 100 \mathrm{MWe}$.

Water Resource Limitations:

- Closed river basins;

- Most surface water sources have their headwaters in California, and as a result considerable upstream depletion exists.

\section{Surface Water:}

- Truckee River

- drainage upstream at $\mathrm{CA} / \mathrm{NV}$ state line is $950 \mathrm{sq}$. miles;

- mean annual discharge is approximately $780 \mathrm{ft}^{3}$ per second upstream;

- downstream annual mean discharge is $650 \mathrm{ft}^{3}$ per second.

- Washoe Lake

- bottom of a closed basin;

- total drainage area is $84 \mathrm{sq}$. miles.

Groundwater:

- Fresh groundwater in Central Lahontan subregion.

\section{Competing Water Demands:}

- Water from Truckee River used for irrigation, municipal, industrial, and recreational purposes. Flow is diverted to Lahontan Reservoir for irrigation and wildife usage.

- Groundwater resources have been highly developed;

- Critical surface supply is $1879 \mathrm{mgd}$, total consumptive demand estimated at 1967 mgd;

- Overall supply vs demand is not anticipated to change.

Conclusion:

Geothermal energy development will place a significant demand on already scarce water supplies. 
Brady Hot Springs KGRA, Nevada

\section{Geothermal Resource Characteristics:}

- Temperature estimated to be $311^{\circ} \mathrm{F}$;

- Capacity 1000 MWe - 300 MWe to be developed prior to 1990;

- Water requirements are estimated to range from 0 to 5500 $\mathrm{ga} 1 / \mathrm{min} / 100 \mathrm{MWe}$.

Water Resource Limitations:

- Surface water is extremely limited;

- Nearest surface water resources $30 \mathrm{~min}$. NE.

Surface Water:

- Humbolt River flows into two reservoirs -

- completely regulated with a flow rate of $200 \mathrm{ft}^{3}$ per second.

\section{Groundwater:}

- Availability is unknown

Competing Water Demands:

- Critical surface supply is estimated to be less than the current consumptive demand;

- Primary use of water is our agriculture;

- $100 \%$ cSs.

Conclusion:

- Since water is all allocated, geothermal development will be difficult. 
Leach KGRA, Nevada

Geothermal Resource Characteristics:

- Resource potential 1500 MWe;

- 100 MWe to be developed prior to 1990;

- Resource temperature $388^{\circ} \mathrm{F}$;

- Binary cycle used for resource development;

- Water requirements $5000 \mathrm{gal} / \mathrm{min} / 100 \mathrm{MWe}$.

\section{Water Resource Limitations:}

- Surface and groundwater resources almost non-existent;

- Groundwater recharge provides some groundwater in eastern portion.

\section{Surface Water:}

\section{Groundwater:}

\section{Competing Water Demands:}

- Integrated consumptive usage estimated to be $3738 \mathrm{Mgd}$;

- Critical surface supply estimated to be $4328 \mathrm{Mgd}$;

- Principal use of water - irrigation.

\section{Conclusion:}

- Water availability will be a significant problem due to noexistent surface and ground water resources. 
Geothermal Resource Characteristics:

- Resource potential set at $1000 \mathrm{MWe}$;

- 250 MWe of installed capacity prior to 1990;

- Fluid temperatures range from $329^{\circ} \mathrm{F}$ to $536^{\circ} \mathrm{F}$;

- Subsurface temperatures of resource estimated at $464^{\circ} \mathrm{F}$;

- High energy liquid dominated;

- Either flash steam system or binary cycle system used for development;

- Water requirements estimated to be 0 to $4500 \mathrm{gal} / \mathrm{min} / 100 \mathrm{MWe}$.

Water Resource Limitations:

- Humboldt River principal stream draining approx. $57 \%$ of area;

- Principal uses irrigation and recreation.

\section{Surface Water:}

- Primary surface water resource - Humboldt River.

\section{Groundwater:}

- Groundwater resources of Humboldt River sub-basin have not been extensively developed.

\section{Competing Water Demands:}

- Integrated consumptive usage estimated to be $3738 \mathrm{Mgd}$;

- Critical surface supply estimated to be $4328 \mathrm{Mgd}$;

- Principal use of water is irrigation.

Conclusion:

- Although surface water is available - it is used primarily for irrigation; groundwater resources are not fully developed. 
Valles Caldera KGRA, New Mexico

\section{Geothermal Resource Characteristics:}

- Resource potential approximately 1500 MWe;

- 350 MWe to be developed prior to 1990;

- Liquid dominated

- Both flash steam process or binary cycle suitable for development;

- Subsurface resource temperatures range up to $600^{\circ} \mathrm{F}$;

o Water requirements 0 to $4000 \mathrm{gal} / \mathrm{min} / 100 \mathrm{MWe}$.

\section{Water Resource Limitations:}

- Both surface and groundwater resources extensively developed. Surface Water:

- Principal source of surface water - Rio Grande River.

\section{Groundwater:}

- Most economically usable groundwater already located and developed.

- Large quantities of brackish water in underground storage.

Competing Water Demands:

- Total consumptive demand $848 \mathrm{Mgd}$;

- Critical surface supply estimated to be $670 \mathrm{Mgd}$;

- Major use of water is for agricultural purposes.

\section{Conclusion:}

- Most surface water already appropriated to agricultural use, but large resources of underground brackish water could be used for development of geothermal energy. 
Mickey Hot Spring KGRA, Oregon

\section{Geothermal Resource Characteristics:}

- Estimated resource potential 160 MWe for 30 years;

- Median temperature $401^{\circ} \mathrm{F}$.

Water Resource Limitations:

- Location in Alvord Desert - water availability scarce.

\section{Surface Water:}

- Surface water not generally available;

- No perennial streams;

- Seasonal lakes.

\section{Groundwater:}

- Poor quality groundwater.

Competing Water Demands:

Conclusion:

- Water availability would be a major problem in the development of geothermal reservoirs. 
Newberry Caldera KGRA, Oregon

Geothermal Resource Characteristics:

- Estimated potential 740 MWe for 30 years;

- Median temperature of reservoir $446^{\circ} \mathrm{F}$.

Water Resource Limitations:

Surface Water:

- Both Paulina Lake and East Lake are located in the center of volcanic water

\section{Groundwater:}

- Located in area of High Desert Groundwater Reservoir.

Competing Water Demands:

Conclusion:

- Availability of water uncertain and unexplored. 
Vale Hot Springs KGRA, Oregon

\section{Geothermal Resource Characteristics:}

- Resource potential estimated to be 800 MWe;

- Sub-surface temperatures of the resource estimated to be $320^{\circ} \mathrm{F}$ to $356^{\circ} \mathrm{F}$;

- Not fully explored; resource characteristics speculative.

\section{Water Resource Limitations:}

- Extensive diversion for irrigation from main source of water - Malhein River.

\section{Surface Water:}

- Malhein River principal surface water resource - with an annual average discharge of $202 \mathrm{ft}^{3}$ per second.

- Flow of river regulated by several reservoirs.:

\section{Groundwater:}

- Thick deposits of permeable sand and gravel yield large quantities of groundwater.

Competing Water Demands:

- Extensive diversion for irrigation purposes.

Conclusion:

- Surface water is used mainly for irrigation, while groundwater resources are not fully known or developed, therefore geothermal energy development would be faced with uncertain and limited supplies of water. 
Alvard KGRA, Oregon

\section{Geothermal Resource Characteristics:}

- Resource potential estimated to be $300 \mathrm{MWe}$;

- Subsurface temperature of resource estimated to be $329^{\circ} \mathrm{F}$;

- Only shallow wells drilled;

- Characteristics not well defined.

Water Resource Limitations:

- Malhein Valley is a closed drainage basin.

Surface Water Sources:

- Surface water sources are scare;

- Trout Creek flowing out of Alvord Lake, has an average flow rate of 10 than $15 \mathrm{ft}^{3}$ per second, and much of it is diverted for irrigation;

- Flow rate is intermittent.

\section{Groundwater:}

- Good groundwater resources - yields from aquifers range from a few hundred to $100 \mathrm{gpm}$;

- Annual total yield from groundwater pumpage is estimated to be 70,000 acre. ft.

Competing Water Demands:

Conclusion:

o Water availability would be unreliable and limited. 


\section{Geothermal Resource Characteristics:}

- Resource potential set at $500 \mathrm{MWe}$;

- Temperature in excess of $284^{\circ} \mathrm{F}$;

- Water requirements range from 0 to $5500 \mathrm{gal} / \mathrm{min} / 100$ MWe depending on flash steam or binary.

Water Resource Limitations:

- Located in a closed drainage basin.

Surface Water Sources:

- Beaver River - drains 272 square miles

- mean annual average discharge is $35.5 \mathrm{ft}^{3}$ per second.

o Rockyford Reservoir

- receives water from a 510 sq. mile drainage basin;

- total storage is $<25,000$ acre, ft.

Groundwater:

o Resources are extensive;

- Underground reservoirs generally large;

- Milford - Berye - Enterprise groundwater basin have enough water to fill Lake Mead.

Competing Water Demands:

- Total consumptive use requirements ${ }^{\circ} 1991 \mathrm{Mgd}$;

- Nearly all water has been appropriated for other uses, i.e., irrigation, agricultural.

Conclusion:

- Geothermal energy development will require water to be transferred from existing usage. 


\section{Roosevelt Hot Springs KGRA, Utah}

\section{Geothermal Resource Characteristics:}

- Temperature $400^{\circ} \mathrm{F}$ to $500^{\circ} \mathrm{F}$;

- Resource potential $1000 \mathrm{MWe}$

- Installed capacity 250MWe in 1990;

- Water requirement 0 to $4500 \mathrm{gal} / \mathrm{min} / 100 \mathrm{MWe}$.

\section{Water Resource Limitations:}

- Closed drainage basin.

\section{Surface Water Sources:}

- Tributaries that flow into/and Rockyford Reservoir;

- Beaver River - $272 \mathrm{sq}$. miles drainage area

- flow into Rockyford Reservoir.

Groundwater:

- Extensive resources

o Milford - Beryl - Enterprise groundwater basin.

Competing Water Demands:

- Virtually all surface water has been appropriated for agricultural uses and domestic uses;

- Groundwater resources developed to near full potential major uses for crop irrigation.

\section{Conclusion:}

- Geothermal development would require that water be transferred from existing usage and may cause a significant problem.

o Water rights - $\$ 1750 /$ acre-ft. 
Cove Fort - Sulphurdale KGRA, Utah

\section{Geothermal Resource Characteristics:}

- Resource potential 1500 MWe;

- 200 MWe installed capacity prior to 1990;

- Temperature $338^{\circ} \mathrm{F}$;

- May be vapor dominated;

- Water requirement 0 to $4500 \mathrm{ga} 1 / \mathrm{min} / 100 \mathrm{MWe}$.

Water Resource Limitations:

o Most water is already appropriated.

\section{Surface Water Sources:}

- Clear Creek flows into the Sevcer River approximately 20 miles east of the KGRA;

- Drainage basin is 164 square miles;

- Mean annual discharge is $24 \mathrm{ft}^{3}$ per second.

\section{Groundwater:}

- Extensive resources

- Miford - Berye - Enterprise groundwater basin.

Competing Water Demands:

- Water resources have been developed to meet their maximum potential;

- Primary use is for irrigation;

- Water law in Utah is governed by the appropriate rights doctrine, and nearly all water has been appropriated.

Conclusion:

- Water will need to be transferred from other uses which may be of significant problem.

o Water rights - $\$ 1730 /$ acre-ft. 
Mount Baker KGRA, Washington

Geothermal Resource Characteristics:

- Subsurface temperature estimated to be $275^{\circ} \mathrm{F}$;

- Characteristics of resource not well defined.

Water Resource Limitations:

- Water supply - plentiful.

Surface Water Sources:

- Several surface springs;

- Mean annual precipitation over 100 inches;

- Baker Lake and Lake Shannon, major surface-water resources.

Groundwater:

- Existence of surface spring indicates a larger quantity of groundwater.

Competing Water Demands:

- Environmentally sensitive and primitive recreational area.

Conclusion:

- Water supply is no problem, but this resource lies within the confines of a national park, so development for geothermal purposes would require coordination with U.S. Forest Service. 